\title{
Entre dos expulsiones: musulmanes y moriscos en Navarra (1516-1610)
}

\author{
Between two expulsions: Muslims and Moriscos \\ in Navarre (1516-1610)
}

\author{
Jesús M. Usunáriz \\ Universidad de Navarra, Pamplona, España
}

Después del decreto de expulsión o conversión forzosa de población musulmana en $\mathrm{Na}$ varra (1516) apenas contamos con estudios sobre la población morisca en el reino o sobre sus relaciones con otras comunidades moriscas en los territorios fronterizos de Castilla y Aragón. Este artículo se centra en tres etapas del conflicto cristiano-morisco: la primera, la de la conversión o expulsión de los mudéjares (1516), y en especial los problemas derivados de la propiedad de las tierras; la segunda relacionada con la rebelión de las Alpujarras de los moriscos granadinos (1568-1570) y el miedo colectivo que afectó a los pueblos navarros de la frontera con Aragón; y, finalmente, la expulsión general (1609-1614), cuando Navarra fue lugar de paso para los desterrados.

Palabras clave: historia social; Navarra; moriscos; expulsión 1516; expulsión 1610; rebelión de las Alpujarras (1568).
There is a general lack of studies on the Muslim population of the kingdom of Navarre or its relations with other Morisco communities in the bordering territories of Castile and Aragon after the decree of 1516 which dictated expulsion or forced conversion. This article focuses on three stages of the Christian-Morisco conflict: firstly, that of the conversion or expulsion of the Mudejars (1516) and, in particular, the problems deriving from issues of landed property; secondly, the Granadan Morisco revolt of the Alpujarras (1568-1570) and the subsequent collective fear which gripped the Navarran towns and villages on the border with Aragon; and finally, it covers the general expulsion of 1609-1614, when Navarre became a place of passage for those who were banished.

Key words: Social History; Navarre; Moriscos; Deportation 1516; Deportation 1610; Rebellion of the Alpujarras (1568).

\section{1516. La expulsión de los mudéjares navarros y sus primeras consecuencias}

Según Domínguez Ortiz y Vincent la R.C. de 12 de febrero de 1502 que ordenaba la conversión forzosa o, en caso contrario, el destierro de la población mudéjar, fue consecuencia de las subleva- 
ciones granadinas de entre 1499 y $1501{ }^{1}$. La orden de noviembre de 1525 , que disponía la conversión de los mudéjares aragoneses antes del 8 de diciembre de ese año, fue fruto de la creciente tensión con los cristianos viejos, manifestada durante las Germanías. Desconocemos, sin embargo, las razones que impulsaron al emperador a adoptar una medida similar en Navarra en 1516, como no fuera la necesaria aplicación de una disposición que afectaba ya al conjunto de la Corona de Castilla, a la que el reino pirenaico se había incorporado un año antes.

Con anterioridad a esa fecha, según los conocidos estudios de García-Arenal $^{2}$ y Carrasco $^{3}$, la población musulmana del reino se concentraba principalmente en la merindad de Tudela, de tal forma que a mediados del siglo XIV suponía entre un $17 \%$ y un $21 \%$ de la población de esa circunscripción ${ }^{4}$. Una población que construyó una comunidad coherente y que pudo o supo mantener la convivencia con sus vecinos cristianos ${ }^{5}$.

No obstante, los temores de los mudéjares navarros por las medidas adoptadas en Castilla en 1502, dieron lugar a importantes salidas, por el puerto de Valencia, de moros de Tudela, especialmente los más pudientes, con destino al norte de África. Hasta 75 tudelanos embarcaron entre 1501 y 1522 , pero de ellos el $94,7 \%$ lo hicieron entre 1503 y $1509^{6}$.

${ }^{1}$ Domínguez Ortiz y Vincent, Historia de los moriscos, p. 19.

2 García-Arenal y Leroy, Moros y judios en Navarra.

3 Carrasco Pérez, "Los mudéjares de Navarra".

${ }^{4}$ Según los datos de Juan Carrasco al finalizar el siglo XIV había mudéjares en 17 localidades: Cadreita, Valtierra, Arguedas y Murillo de las Limas, Cintruénigo -contingente reducido a su mínima expresión tras 1348-, Corella -aljama nutrida, pero a comienzos del XV en vías de desaparición-, Murchante, Cascante, Monteagudo, Pédriz, Barillas, Vierlas, Ablitas, Fontellas, Ribaforada, Cortes y Tudela. En total medio millar de fuegos de moros, sobre un total de 19.000 en la segunda mitad del siglo XIV, 2,68\% del total de la población del reino y el $21 \%$ de la merindad de Tudela. Carrasco Pérez, "Los mudéjares de Navarra", pp. 81-88.

${ }^{5}$ Esto no significa, sin embargo, que debamos olvidarnos de que las restricciones y persecución de los moros fueron muy anteriores a las que acabaron con su expulsión, como se plasma en las sinodales aprobadas en los obispados de Pamplona y Calahorra contra ellos, pero especialmente contra los conversos y contra las relaciones entre cristianos y moros. Sínodo de Diego de Zúñiga en Logroño en 1410, que vuelve a reproducirse en el de 1539 y en el de 1553. También en el de Pamplona de 1354 y 1499. García García, Synodicon hispanum, pp. 354 y 555.

${ }^{6}$ Así lo atestigua Salvador, "Sobre la emigración mudéjar", pp. 54-55. El 8,68\% de los que partieron eran navarros, muy lejos de los 59,69\% aragoneses. También 
Tras la conquista castellana del reino navarro (1512) nada parecía que fuese a cambiar. El 4 de octubre de ese mismo año Fernando el Católico se presentó en Tudela y antes de entrar juró los fueros de la ciudad a requerimiento de «la universidad de cristianos y de la aljama de moros» y confirmó los privilegios de la morería tudelana ${ }^{7}$.

No obstante, poco después, el nuevo monarca, Carlos de Gante, firmaba la orden para que se aplicara en Navarra -Goñi Gaztambide señala el 1 de mayo de $1516^{8}$ - la disposición castellana de 1502 que ordenaba la conversión inmediata de los musulmanes y la salida de aquéllos que no lo hicieran. La aplicación del decreto de expulsión, si bien inmediata, tuvo su prolongación en los años siguientes. Todavía entre 1517 y 1520 se emitieron protocolos de moros en Tudela ${ }^{9}$.

Es probable, como señala Epalza, que «con las conversiones forzosas, tras la anexión [...] muchos musulmanes se pasaran al vecino Aragón, donde aún tuvieron libertad de culto hasta $1526 »{ }^{10}$. Otros muchos, sin embargo, pasaron, como años antes, al norte de África, ya que según López de Coca, una provisión publicada probablemente el mismo año de 1516 permitía que «mil cabezas de moros de los del regno de Navarra se pudiesen ir e pasar a los reinos de África con sus mujeres y haciendas» ${ }^{11}$. De hecho, en el registro de salidas

por otros autores: García-Arenal, "Un nuevo documento" y López de Coca, "Notas y documentos", pp. 155-156. Cabe preguntarse, tras examinar los datos y documentos de la profesora Salvador, por qué 1517 fue el año de mayor éxodo musulmán a través del puerto de Valencia. Para esta autora es probable que fuera la llegada de Carlos I al trono lo que provocó el temor de los moros aragoneses de que el nuevo monarca no ratificaría el compromiso de Fernando el Católico en 1510, en las Cortes de Monzón, de no forzar la conversión y el exilio de la población mudéjar. A mi modo de ver, el decreto de expulsión de los moros navarros en 1516 corroboraría entre los aragoneses este temor. Pero también es posible especular con que una parte importante de los que se declararon moriscos aragoneses en Valencia fuesen de origen navarro, exilados primero en Aragón.

${ }^{7}$ Citado por García-Arenal, "Los moros de Tudela", pp. 77 y 84, nota 26.

${ }^{8}$ El 1 de mayo es la fecha de la venta de los bienes de moros de Cortes, en donde se hace referencia a la «provisión y mandamiento» de los reyes Carlos y Juana, por lo que es, con probabilidad, anterior. AGN [Archivo General de Navarra], Comptos. Documentos, Caja 168, n. ${ }^{\circ}$ 68, f 2r.

9 García-Arenal, "Los moros de Tudela", pp. 81-82.

${ }_{10}$ Epalza, Los moriscos, pp. 75-76. Señala, sin embargo, que si bien se atestigua la presencia de algunos moriscos en la Navarra del XVI, no había constancia de encausados moriscos navarros en la Inquisición, algo que no es del todo exacto. También GarcíaArenal considera que la población islámica emigraría hacia Aragón, o bien acabarían convirtiéndose. Otros volverían a Navarra después del decreto de conversión forzosa de los moriscos aragoneses, García-Arenal, "Los moros de Tudela", p. 80.

${ }^{11}$ López de Coca, "Notas y documentos", p. 156. 
entre 1498-1522, el año más nutrido de la emigración mudéjar fue el de 1517, lo que hace sospechar que buena parte de ellos fuesen originarios del reino navarro ${ }^{12}$.

¿Se fueron todos los mudéjares en 1516? Según Orta, salvo casos excepcionales, «no quedó ningún morisco residente en la comarca de Tudela. Y si lo hizo su conversión fue tan sincera que se perdió todo recuerdo anterior» ${ }^{13}$. Goñi Gaztambide señala por ejemplo, que 29 musulmanes de Valtierra prefirieron el bautismo ${ }^{14}$. Sí está comprobado que en Tudela, a partir de esa fecha se multiplicaron las ventas de los «bienes terribles»-tierras-e inmuebles de moros -García-Arenal ha encontrado las actas notariales de venta de unos $200^{15}$-, mientras que los comunales de la aljama pasaban a manos del fisco. No obstante, la despoblación fue tal -Yanguas hablaba de 200 casas abandonadas en la ciudad de la Ribera, lo que muestra la importancia de esta aljama en el conjunto hispano- que el municipio se quejaba en 1516 de que la morería, sin habitantes, podía ser refugio de ladrones y «facer muchos males» y de que por «el destierro de los moros ha quedado la morería desta ciudad despoblada y [...] esta ciudad muy dainada» ${ }^{16}$. Estos bienes fueron solicitados por el ayuntamiento de Tudela, lo que le permitió la fundación y construcción de la iglesia de San Juan, hoy desaparecida ${ }^{17}$. Otras localidades

12 López de Coca, "Notas y documentos", p. 157.

${ }^{13}$ Orta Rubio, "La Ribera tudelana", p. 804.

${ }^{14}$ Goñi Gaztambide, Historia de los obispos, p. 97.

${ }^{15}$ García-Arenal y Leroy, Moros y judios en Navarra, pp. 19-20. Estas ventas se iniciaron el 28 de abril de 1516 y continuaron durante los meses de mayo y junio. Uno de los beneficiados por la venta de bienes en Tudela sería García Pérez de Beraiz «alcaide del castillo de dicha ciudad y meridad» y baile y juez ordinario de los moros de la ciudad y su merindad. García-Arenal, "Un nuevo documento", pp. 456-457. De hecho su hijo, Francisco Baraiz, en nombre de su padre, «entró y tomó posesión actual, real y corporal de las tiendas y botigas de zapatería y ferrerías y de dos fornos y una casa llamada de la carnecería, que los moros que solían vivir en la morería de la dicha ciudad solían tener» el 24 de mayo de 1516. AHPT (Archivo Histórico de Protocolos de Tudela), Fernando de Agramont, caja 47-2, n. ${ }^{\circ} 11$. A las de Tudela hay que sumar las ventas de unos 60 vecinos moros de Cortes, 27 de Murchante, 22 de Ablitas, 13 de Ribaforada, 6 de Pédriz, 6 de Valtierra y 4 de Fontellas. García-Arenal y Leroy, Moros y judios en Navarra, p. 20, nota 19 y García-Arenal, "Los moros de Tudela".

${ }^{16}$ Orta Rubio, "La Ribera tudelana", pp. 740 y 803. La carta del ayuntamiento de Tudela de 23 de mayo de 1516 en García-Arenal y Leroy, Moros y judíos en Navarra, pp. 130-131.

17 García-Arenal, "Los moros de Tudela", pp. 78-79; Orta Rubio, "La Ribera tudelana", p. 777. La carta de los reyes concediendo la conversión de las mezquitas de Tudela en iglesias, fechada en Bruselas el 28 de junio de 1516 en García-Arenal y 
como Murchante o Murillo también quedaron despobladas tras la expulsión ${ }^{18}$. Bien es cierto que, como nos recuerda García-Arenal, las ventas que se hicieron en Tudela fueron «con pacto de retro» es decir, que las propiedades se devolverían a sus dueños si estos abrazaban la fe cristiana ${ }^{19}$. En las Cortes de 1517 se pidió permiso para que los moros pudiesen introducir mercancías en Tudela ${ }^{20}$. Años más tarde, hacia 1597, un morisco residente en Tudela recordaba aquella expulsión y las ventas de tierras con indudable malestar:

esta heredad fue vendida en el tiempo del rey Don Juan ${ }^{21}$ por una gayata ${ }^{22}$, y aquella otra heredad por un capote, que eran de los moriscos. Y tuvo la culpa el dicho rey porque mandó desterrar los moros deste reino de Navarra porque no se querían volver cristianos, en lo cual les hizo grandísimo agravio porque ¿qué se le daba a él de que fueran moros si ellos lo querían ser? ${ }^{23}$.

Pero además de la pérdida de pobladores, otro problema que se planteó fue el de la propiedad de las tierras hasta entonces cultivadas por la población mora. Su situación era ambigua: si bien según apunta el Fuero General de Navarra todos los moros eran del rey - «es a saber que todos los moros e las moras en sus personas son del rey» ${ }^{24}$ - más difícil es llegar a precisar la propiedad de las tierras cultivadas por ellos. Según Ozaki, en su estudio sobre la población mudéjar medieval «se puede considerar la situación de los moros campesinos como enfiteutas del rey» ${ }^{25}$. Opinión que difiere del criterio de García Arancón para quien, a mediados del siglo XIII, en las seis aljamas de realengo de Tudela, Cortes, Corella, Valtierra, Ablitas y Vierlas, la mayoría de los moros eran campesinos que cultivaban las heredades de la Corona como villanos dependientes, renteros

Leroy, Moros y judios en Navarra, p. 131. También hace referencia Goñi Gaztambide, Historia de los obispos, p. 97.

${ }_{18} \mathrm{Y}$ existía la intención de que fueran ocupadas por cristianos: «nos ha sido fecho relación que algunos cristianos tienen voluntad de las poblar e habitar», García-Arenal y Leroy, Moros y judios en Navarra, pp. 131-132.

19 García-Arenal, "Los moros de Tudela", pp. 80-81.

${ }^{20}$ AGN, Legislación general, leg. 1, carp. 27, f 13r. Las peticiones fueron decretadas en Valladolid, el 22 de marzo de 1518.

${ }^{21}$ Se refiere, equivocadamente, al rey Juan de Albret, que sí fue responsable de la expulsión de los judíos de Navarra.

22 Gayata: «Lo mismo que cayada o cayado. Es voz usada en Aragón» [Aut.]

${ }^{23}$ AHN [Archivo Histórico Nacional], Inquisición, lib. 834, f 789v.

${ }^{24}$ Utrilla, El Fuero General de Navarra, pp. 95-96

${ }^{25}$ Ozaki, "El régimen tributario", p. 473. 
o aparceros ${ }^{26}$. García-Arenal mantiene un criterio intermedio pues si bien, «a ciertos efectos hay que considerarlos -a los moros- de realengo», también abonaban -además de los tributos al rey- un gran número de tributos a señores particulares ${ }^{27}$. Todo apunta, sin embargo, a que el momento de la expulsión de la población mudéjar fue aprovechado por los señores para hacerse con sus tierras, por encima de los posibles derechos de los monarcas. En un informe del patrimonial sobre las rentas reales en la merindad de Tudela se daba la alarma sobre la merma que estaba sufriendo aquel patrimonio. Según este los «muchos moros» que vivían en las localidades de Cortes, Ribaforada, Fontellas, Ablitas, Pédriz, Cascante, Murchante y Valtierra, antes de su expulsión, pagaban al rey la alcabala, además de otras contribuciones como «aguaquela, juguería, bracería, marçago ${ }^{28}$, gallinas y huevos y otras servidumbres como vasallos pecheros y [cofres] del rey». Tras su marcha, sus posesiones fueron ocupadas por cristianos, que si bien pagaban la alcabala no hacían lo mismo con el resto de contribuciones que con anterioridad habían asumido los moros. Por otra parte se había enajenado la jurisdicción baja y mediana de las poblaciones a favor de señores particulares -Cortes al príncipe de Salerno, Ribaforada, Urzante y Pédriz al comendador Pasquier, Fontellas a Antonio de Gante señor de Fontellas, Ablitas a su señor y Valtierra a León de Peralta. Pero, sobre todo, estos señores:

se aplican los montes y tierras, paztura y rotura en propiedad y posesión y lo venden y arriendan a quien ellos quieren y por bien tienen con sotos y lexas y vagos y casas, casales, huertos, hortales, fornos y molinos, ríos y pesquerías ${ }^{29}$.

Es probable que, gracias al informe del patrimonial, se tomaran medidas para la recuperación de los bienes reales que habían estado en manos de la población musulmana. Por una R.C. fechada en Bruselas el 16 de octubre de 1516, los reyes Carlos y Juana ordenaron al virrey que

los bienes que dejaron los judíos y moros que se fueron de ese reino que pertenescen a mi cámara e fiesco que conforme a justicia les adjudicásedes a ella et

${ }^{26}$ García Arancón, “Algunas precisiones”, p. 249.

${ }^{27}$ García-Arenal y Leroy, Moros y judios en Navarra, pp. 51-54.

28 Probablemente se refiera a marzalga: «Cierto género de pecho que se pagaba por el mes de marzo, como martiniega por San Martín» [Cov.].

${ }^{29}$ Relación de bienes del patrimonio real en la merindad de la Ribera. AGN, Papeles Sueltos de Comptos. Primera Serie, leg. 7, n. ${ }^{0} 52$. 
los pusiesedes en poder de personas llanas e abonadas que los regiesen e acudiesen con ellos e con los fructos e rentas dellos a la persona que por nos fuese mandado ${ }^{30}$.

No obstante, en el proceso iniciado, fueron los señores, como hemos visto, quienes tomaron ventaja. En Valtierra, por ejemplo, la mezquita y las tierras anejas fueron ocupadas por León de Peralta hasta que finalmente, en 1527, fue condenado al abandono de la jurisdicción de la villa y a la devolución de todas las rentas percibidas por él y sus antecesores hasta entonces, que pasaban a ser de patrimonio real ${ }^{31}$.

En 1524 acudían a los tribunales reales el conde de Ribagorza y el duque de Villahermosa: el primero alegaba haber comprado el 1 de mayo de 1516 todos los bienes de los moros de Cortes, pues los moros «solían tener e poseer aquellas e aquellos por e como suyos e tales habidos, tenidos e reputados» ${ }^{32}$. Algo similar a lo que era práctica habitual entre los labradores pecheros del reino ${ }^{33}$. Es decir, como afirmaba un testigo, los bienes de los moros eran suyos y los «cuartos» $\mathrm{y}$ «quintos» que pagaban a los señores no suponían un reconocimiento de los derechos de propiedad del duque de Villahermosa ${ }^{34}$. Para el de Villahermosa, sin embargo, los moriscos no podían vender lo que no era suyo, ya que las tierras pertenecían al duque, como señor jurisdiccional y dueño de sus términos, y los moros eran «colonos tributarios»o, más precisamente, «infetiotas» que pagaban sus rentas al duque «en recognoscimiento del dicho dominio y propriedat» ${ }^{35}$, al igual que había ocurrido con los bienes de los moros de Ablitas, Ribaforada y Valtierra, que habían quedado en manos de los señores tras la orden de destierro "por ser las tierras de los señores en propiedad y dominio y ellos ser renteros y tributarios» ${ }^{36}$. Villaher-

${ }^{30}$ Archivo de Protocolos de Tudela. Pedro Copin de Lorenz. Citado por GarcíaArenal y Leroy, Moros y judios en Navarra, pp. 132-133. El virrey encargó el cumplimiento de esta orden a Johan de Gamboa, el 2 de enero de 1517.

${ }^{31}$ Goñi Gaztambide, Historia de los obispos, p. 238; Usunáríz, "La política de incorporación de señoríos", pp. 176, 180, 184 y 189.

${ }_{32}$ AGN, Tribunales Reales. Procesos, n. ${ }^{\circ}$ 000001, fol. 16r.

33 AGN, Comptos. Registros, Primera Serie, n. ${ }^{\circ}$ 549, fol. 15 r.

${ }^{34}$ AGN, Comptos. Registros, Primera Serie, n. ${ }^{\circ} 549$, fol. 30r y ss.

35 AGN, Tribunales Reales. Procesos, n. ${ }^{\circ}$ 000001, fol. 18r.

${ }^{36}$ AGN, Comptos. Registros, Primera Serie, n. $^{\circ} 549$, fol. $18 \mathrm{r}$ y ss. Testimonios muy interesantes de los testigos sobre los casos de Ribaforada y de Ablitas, fol. 124v-125r y fol. 156r-156v. En el caso de Ablitas cuando los moros de la villa fueron desterrados 
mosa demostró que los moros de Cortes sí tenían la obligación de pedir licencia al señor de Cortes para vender solares y tierras, e incluso para poder casar a sus hijas ${ }^{37}$; pero Ribargoza sacó a la luz una sentencia compromisal de 1489 , por la que se aprobó que el duque de Villahermosa fuera el dueño de las tierras que no tuvieran propietario, mientras que el resto de las heredades quedaría en manos de sus vecinos, cristianos o moros. En definitiva, según Yanguas, los moros vendieron en 1516 a Alonso Gurrea, lo que era suyo ${ }^{38}$.

Ahora bien, si esto ocurría con los bienes de los moros desterrados, ¿cuál fue el destino de las posesiones de aquellos que, convertidos al catolicismo, permanecieron en Navarra? A finales de 1530, Johan de Cortes y Adán Eldoro, vecinos de Ablitas, moriscos, se atrevían a denunciar al señor de Ablitas, D. Antonio Enríquez de Navarra porque los amenazaba y

les va tomando por fuerza y contra su voluntad las posesiones heredades que ellos y sus antepasados de tiempo inmemorial a esta parte han tenido y poseído, tienen y poseen de presente, haciendo como les hace derribar las ribas ${ }^{39}$ y cequias de sus dichas heredades en que resciben mucho daño, mostrándose en todo absoluto y deciéndoles que si van a labrar sus dichas heredades les hará maltratar. En todo lo cuoal por ser el dicho don Antonio persona de cualidat y más poderoso que los suplicantes no [se] pueden defender ${ }^{40}$.

Según el señor, él era el poseedor de las «casas y heredades, tierras e haciendas moriegas» de los moros que vivían en Ablitas, y así lo había obtenido por sentencia su madre, Isabel de Peralta. Aquellos moros, «hasta que salieron deste reino» pagaban el cuarto y el quinto de las cosechas de las tierras moriegas, y el seixeno de los montes, y con ellas otro conjunto de servidumbres ${ }^{41}$ : el cuarto y el quinto,

vendieron sus haciendas a la señora de Malón, al señor de Barillas y a la familia de los Tornamiras de Tudela, pero la señora de Ablitas se opuso a la venta «como señora propietaria que pretendía ser de las dichas hacienda». Además se hizo con aquellas haciendas de moros y las repartió entre «renteros cristianos».

37 En 1509 constan al menos dos permisos solicitados por moros a la duquesa de Villahermosa para vender solares y casas AGN, Comptos. Documentos, Caj. 168, n. ${ }^{\circ} 50$ y n. ${ }^{\circ}$ 48. y una petición de licencia para casar a una hija, AGN, Comptos. Documentos, Caja. 168, n. $^{\circ} 49$.

38 Yanguas y Miranda, Diccionario de Antigüedades, vol. I, pp. 258-259.

39 Riba: «Por ripa, que vale ribera» [Cov.].

${ }^{40}$ AGN, Tribunales Reales. Procesos, n. ${ }^{\circ} 008597$.

${ }^{41}$ Sobre el sistema impositivo en las aljamas rurales de la Ribera de Navarra: Ozaki, "El régimen tributario", pp. 437-484. 
«juvería» ${ }^{42}$, «alguaquela» ${ }^{43}$, «marzago» ${ }^{44}$, y además de estos pagos hacían «azofras»y «otras servitudes» ${ }^{45}$.

Quienes testificaron por una y otra parte corroboraron lo señalado por ambos, pero con matices. Los testigos de los moriscos afirmaron tajantemente que aquellas tierras pertenecían a los antepasados de Johan de Cortes y de Adán Eldoro, y como tales dueños las habían trabajado, a pesar de los desmanes que tuvieron que sufrir por parte de los criados de Enríquez de Lacarra. Los testigos de don Antonio no fueron tan categóricos. Cuando los moros de Ablitas «fueron desterrados y echados del reino» -y no antes- Isabel de Peralta, se hizo con todas las casas y tierras que habían abandonado. Pero no lo hizo fácilmente pues tuvo que pleitear contra un tal mosén Coloma, aragonés, por algunas de las propiedades, y la supuesta sentencia favorable hacia doña Isabel nunca se presentó.

Las tres sentencias, la del comisario delegado por la Corte en mayor en Tudela -de 15 de diciembre de 1530-, la de la Real Corte, de 15 de marzo de 1531 y la del Consejo de 24 de enero de 1532 , fueron favorables a Adán y Juan, «moriscos, nuevos convertidos» ${ }^{46}$. Es más, este pleito se explica mejor si se relaciona con la creciente oposición existente en Ablitas contra el señor y su jurisdicción, en la que no faltaron tampoco las amenazas de Enríquez de Lacarra ${ }^{47}$

42 Juvería, iugería, iuvería: «parece que esta gabela se imponía sobre cada yugo, de lo que derivaría su nombre», Ozaki, "El régimen tributario", p. 470.

43 Alguaquela: tributo por el agua. García-Arenal y Leroy, Moros y judios en Navarra, pp. 53.

44 Ver nota 28.

45 Azofra: pecha «que se reducía a la obligación que los moros tenían de cavar a sus expensas las viñas del señor y traer las uvas al cubo». Yanguas y Miranda, Diccionario de Antigüedades, vol. II, p. 356. Sobre la sofra o azofral, Ozaki, "El régimen tributario", pp. 467-470, y todo apunta, según este autor, a que era una prestación personal que variaba según los lugares y que podía suponer «jornada de trabajo, transporte, reparación del castillo, mezquita o iglesia, labores de cultivo, transporte de alimentos a la casa del señor, vendimia, mantenimiento de la acequia, defensa de la fortaleza y prestación de animales para el transporte en tiempo de guerra, etc.».

${ }^{46}$ AGN, Tribunales Reales. Procesos, n. ${ }^{\circ}$ 008597. De hecho en el siglo XVIII los condes de Ablitas, si bien seguían percibiendo el cuarto y quinto de las tierras de la villa, las posesiones del conde se consideraban de dominio compartido entre los labradores y el señor. Usunáriz, Nobleza y señoríos, p. 151.

47 Enríquez amenazó a varios vecinos de Ablitas contrarios a la jurisdicción del señor con que les había de «dar de palos si dicen que no son sus vasallos y de su jurisdicción y contravienen sus mandatos». AGN, Papeles Sueltos de Comptos. Primera Serie, leg. 152, carp. 8 . 
y también con la reiterada resistencia al pago de cuartos y quintos ${ }^{48}$. El pleito de Ablitas me parece de especial interés, ya que abre el tema no solo de la propiedad sino el de los derechos individuales de los moriscos. De alguna manera, todo apunta a que con el bautismo los mudéjares convertidos adquirieron la condición de navarros de pleno derecho, al igual que llega a apuntar Colás sobre los moriscos aragoneses ${ }^{49}$.

De pleno derecho, sí, pero bajo estrecha vigilancia. Los descendientes cristianos de los antiguos moros, como en otras partes de la Monarquía, debieron sujetarse a un determinado comportamiento muy apartado de veleidades musulmanas. En 1535 el inquisidor Martín Pérez de Oliván (el documento está fechado en Cascante, el 4 de junio) dio orden sobre el modo de conducirse los moros convertidos en la villa de Monteagudo, aunque, como bien señala Goñi Gaztambide, la orden tenía un alcance general, ya que Oliván desempeñaba el cargo «inquisidor apostólico contra la herética pravedad y apostasía en todo el reino de Navarra, obispado de Calahorra La Calzada y su partido». Así, en la visita que llevó a cabo ordenó que los conversos se esforzaran en aprender las oraciones católicas, asistir a las misas y divinos oficios, confesarse y comulgar, además de recibir doctrina cristiana todos los domingos, cumplir con los ayunos y vigilias ${ }^{50}$. Entre la reforma de costumbres, se les animaba a criar cerdos, comer tocino y beber vino y a utilizar exclusivamente los nombres que adoptaron cuando se hicieron cristianos. Se les instaba, además, a evitar a los moriscos aragoneses «porque de su prática y conversación les podría venir mucho daño». Todo apunta - escasa presencia de moriscos navarros en los tribunales inquisitoriales, pocas o nulas referencias a comunidades moriscas diferenciadas- a que quienes permanecieron en el reino se integraron, en su mayoría, a un nuevo modus vivendi, en un proceso de aculturación que aún desconocemos.

${ }^{48}$ Usunáriz, Nobleza y señorios, p. 195. En otros lugares el señor fue considerado pleno propietario. El señor y futuro marqués de San Adrián era dueño de la práctica totalidad de las tierras de Monteagudo. Sus propiedades estaban divididas en quiñones, $\mathrm{y}$ en unas los renteros pagaban un tercio de lo que se recogiera en tierras «moriegas» y una cuarta parte de lo cosechado en las «cristianegas», 203.

${ }_{49}$ Colás Latorre, "Los moriscos aragoneses", p. 235.

${ }_{50}$ AGN, Negocios Eclesiásticos, leg. 1, carp. 39. El documento es una copia del original que está en el archivo del marqués de San Adrián, sección Monteagudo, leg. 2, n. ${ }^{\circ}$ 21. Cit. también por Goñi Gaztambide, Historia de los obispos, pp. 238-239. 
Salvo estas breves referencias, desde la fecha de 1516 poco sabemos de la presencia de elementos moriscos en Navarra, o de las relaciones entre antiguos musulmanes y las comunidades moriscas aragonesas, al menos hasta la década de los años 60. Es cierto que han llegado testimonios de que los moriscos aragoneses trasegaban continuamente por Navarra como trajineros o como vendedores ambulantes con el visto bueno de las autoridades: los regidores de Tudela, por ejemplo, pidieron a Carlos V que «los dichos moros puedan ir y venir e entrar en esta ciutat con sus mercaderías dos o tres días en la semana» ${ }^{51}$. Sin embargo, a partir de los sesenta y, sobre todo, los setenta del Quinientos, asistimos a un recrudecimiento en las medidas y un endurecimiento en las actitudes hacia los moriscos.

\section{La rebelión de las Alpujarras y la tensión en las relaciones con los moriscos}

A partir de 1560 comenzaron a aplicarse en Navarra medidas similares a las aprobadas por la Inquisición aragonesa contra los moriscos que emigraban a Francia. Fue el 10 de octubre de ese año cuando Miguel Daría de Ezcároz, escribano de la curia eclesiástica de Pamplona y del Santo Oficio de la Inquisición de Pamplona, recibió la orden del tribunal de Calahorra de detener a los moriscos ${ }^{52}$, si bien fueron las autoridades civiles las que realizaron algunas detenciones ${ }^{53}$. No obstante la persecución y, especialmente, la actitud hacia los moriscos, se radicalizaría como consecuencia de la rebelión de las Alpujarras.

Si bien hubo agitaciones anteriores ${ }^{54}$, la sublevación de los moriscos granadinos en la Navidad de 1568 -fruto de las medidas de

51 Orta Rubio, “La Ribera tudelana”, p. 746. Para Reglá en Asturias, Vizcaya y Navarra, el morisco se identifica con el artesano o vendedor ambulante. Reglá, Estudios sobre los moriscos, p. 198.

52 AGN, Tribunales Reales. Procesos, n. ${ }^{\circ} 001168$.

53 En octubre de 1560 fueron apresados 21 vecinos moriscos procedentes de Urrea que intentaron pasar a Francia, a San Juan de Luz, con la ayuda del trompeta de Pamplona, Miguel Marruecos, morisco de Épila. Portaban dineros y joyas. A pesar de las presiones del comisario del Santo Oficio para que le fuesen entregados, la Corte se hizo con el caso y condenó a un tercio de ellos a la pérdida de sus bienes, quedando todos los demás libres. AGN, Tribunales Reales. Procesos, n. ${ }^{\circ} 001168$.

${ }^{54}$ Por ejemplo la ocupación de Ciudadela en Menorca, en 1558, que sembró la 
represión aprobadas, especialmente la de 17 de noviembre de 1566-, supuso un corte radical del que no hubo vuelta atrás: el temor a la connivencia de aquellos con el berberisco y el Turco, la necesidad de una monarquía fuerte gracias a la unidad religiosa, la intransigencia de algunos oficiales reales, dio pie a la política de conversión forzosa, seguida de una campaña de erradicación de lengua y costumbres y de expoliación de bienes, que desembocó en una guerra llena de episodios de gran crueldad por ambas partes. Solo en este clima de crispación, odio y miedo ${ }^{55}$, pueden entenderse los años setenta, donde el rumor sobre las atrocidades, sobre conspiraciones moriscas anunciadoras de un pronto levantamiento general -la quinta columna en potencia de la que habló Reglá ${ }^{56}$, o el eco de los tratos secretos con los levantiscos protestantes del sur de Francia, fue constante como relatan en un sinfín de testimonios recogidos por Reglá, Domínguez Ortiz, Vincent, Cardaillac, García-Arenal, Contreras, Monter, Salvador o Benítez Sánchez-Blanco, entre otros ${ }^{57}$. Así en uno de los informes de los inquisidores de Zaragoza se decía:

[...] Que la orden que han de tener para el levantamiento es que don Antonio de Portugal y el Príncipe de Orange tienen concertado con los moros de Marruecos por medio de algunos mercaderes portugueses y moriscos granadinos que acudan por aquella parte y que el Príncipe de Bearne se ha visto con el rey de Francia y pedídole la palabra que le dio cuando se casó con su hermana que le daría gente para tomar a Navarra y que tiene concertado con los moriscos de Aragón que le han de favorecer. Y que para lo de Valencia aguardan la armada del Turco, que no saben por dónde vendrá, más de que han de estar en Argel para el 11 de agosto.

Que también tienen concertado con los franceses que han de meter el alquitrán por Roncesvalles en pelotas de sebo y llevarlo a los moriscos del Alcar[r]ia para quemar con él las galeras y bajeles de cristianos ${ }^{58}$.

alarma de las autoridades y la agitación de las poblaciones moriscas, primero en Valencia y después, en 1559, en el valle del Ebro, Reglá, Estudios sobre los moriscos, p. 201; o el intento fallido de desarme de cristianos nuevos en Aragón de 1559. Carrasco Urgoiti, El problema morisco, p. 49 y ss.

${ }_{55}$ Sobre el pánico entre los cristianos: Domínguez Ortiz y Vincent, Historia de los moriscos, pp. 57-58.

${ }_{56}$ Reglá, Estudios sobre los moriscos, p. 195.

57 Domínguez Ortiz y Vincent, Historia de los moriscos, pp. 57-58; Cardaillac, Moriscos y cristianos, cap. III; García-Arenal, Los moriscos, pp. 217-221; Monter, La otra Inquisición, pp. 112-115; Salvador, Felipe II; Benítez Sánchez-Blanco, Heroicas decisiones, cap. III.

${ }^{58}$ Domínguez Ortiz y Vincent, Historia de los moriscos, pp. 61-62.

Al-Qantara XXXIII 1, 2012, pp. 45-81 ISSN 0211-3589 doi: 10.3989/alqantara.2010.002 
Quizás, como señala Colás Latorre, todo este conjunto de conspiraciones y posibles contactos de los moriscos con los enemigos de la Monarquía, fuera un tópico ${ }^{59}$. El apoyo del otomano no fue determinante sino efímero; es más que posible que los bearneses, en lucha permanente en Francia, no tuvieran capacidad logística para preparar nada al otro lado de la frontera. Es cierto que muchos de los testimonios carecen de credibilidad. También lo es que la sublevación en Aragón nunca se materializó, gracias a las concordias negociadas con los nuevamente convertidos. Pero, a pesar de todo, el miedo no fue un tópico, ni tampoco la tensión social existente, sino la construcción - como señala Colás- de un entramado ideológico elaborado por la Inquisición -y por la administración real- contra una minoría contra la que habían fracasado todos sus intentos de integración ${ }^{60}$. Tras las Alpujarras, como bien apunta Rafael Carrasco, se pasó del recelo al miedo, y con él llegó la multiplicación de rumores de toda clase ${ }^{61}$.

Especialmente ilustrativa es la información que, por encargo del virrey de Navarra, llevó a cabo el licenciado Pedro Lope de Lugo, fiscal «de los lugares de la frontera, sobre las costas vedadas que dél se pasan a otros reinos, especialmente, al de Aragón, y de los moriscos que viven en los dichos pueblos de la frontera y de las armas y munición que ocultan y pasan a los de Aragón. Y ansí mismo de la alianza, amistad y confederación que tienen con los dichos moros de Aragón. La cual hice por mi propia mano, sin intervención de escribano real, según y de la manera que $\mathrm{Su}$ Excelencia me lo mandó por su carta. Comenzose a hacer el 27 del mes de marzo de 1570» ${ }^{62}$.

Dicho informe daba cuenta, pueblo por pueblo, a través del testimonio de testigos -la mayor parte de ellos alcaldes y oficiales reales-

${ }^{59}$ Colás Latorre, "Cristianos y moriscos en Aragón". No obstante, como señala Beatriz Alonso, a lo largo del siglo XVI «son patentes las situaciones en las que el amparo otomano a los asuntos moriscos se hace notar de manera notable a través de Argel». Alonso Acero, "El norte de África", pp. 95-96. Véase también la situación de psicosis frente al peligro musulmán en el Mediterráneo en tiempos de Felipe III en Bunes, "Los moriscos en el mundo mediterráneo".

${ }^{60}$ Colás Latorre, "Los moriscos aragoneses", pp. 244-245.

${ }^{61}$ Carrasco, Deportados, p. 131 y ss.

${ }^{62}$ AGN, Tribunales Reales. Procesos, n. ${ }^{\circ}$ 068395. Este documento, por la imagen que da de la situación es muy similar a la «Relación de las culpas, indicios, rumor y sospechas que ha habido del levantamiento de los moriscos del reino de Aragón... y fundamento de ellas elaborada por la Inquisición aragonesa» que cita Carrasco, Deportados, p. 160 y ss. 
de la presencia de población morisca y su comportamiento. El primer dato es incuestionable: la presencia de comunidades de moriscos en Navarra era mínima (Mapa 1), en torno a una treintena de vecinos identificados repartidos entre ocho localidades -Tudela, Monteagudo, Murchante, Pédriz, Cortes, Cascante, Valtierra y Ablitas. Algunos, como los de Tudela, Murchante o Pédriz no levantaban sospechas y era considerados «buenos cristianos».

Mapa 1. Presencia de moriscos en Navarra según el informe del licenciado Pedro Lope de Lugo (1570)

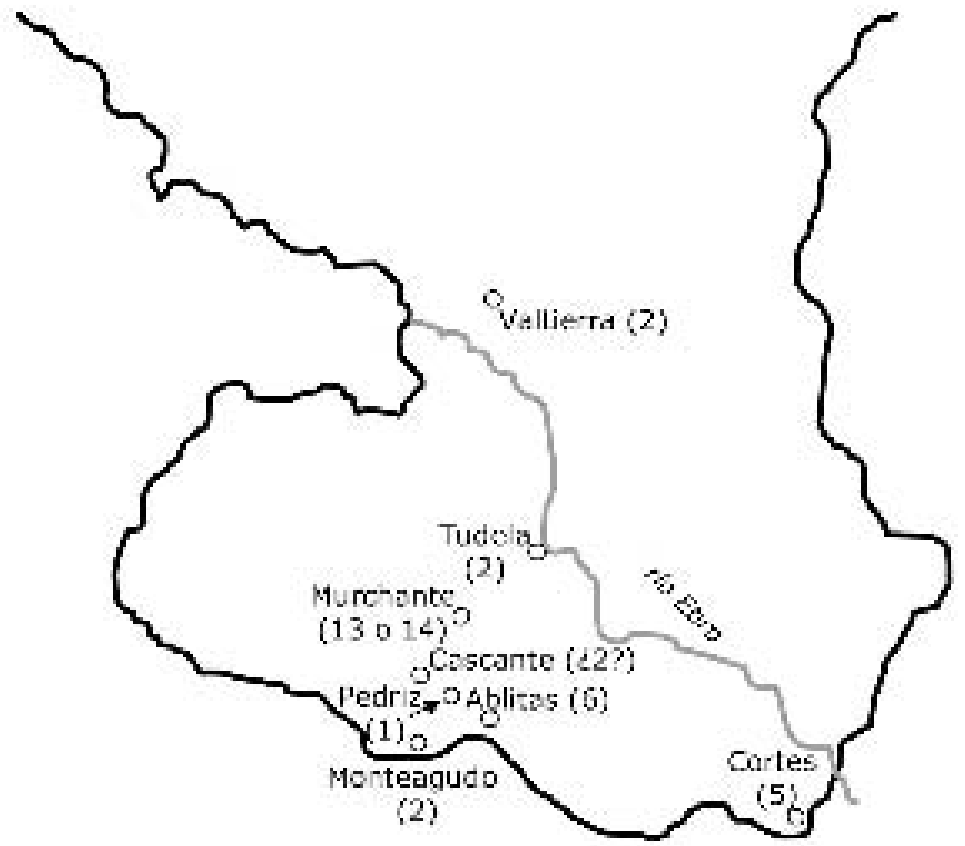

Fuente: Elaboración propia.

No obstante, el informe mostraba su preocupación por la existencia de contactos entre algunos moriscos navarros con los aragoneses y, sobre todo, por el importante trasiego de estos aragoneses por el reino. Los testimonios de Tudela confirmaban la asidua presencia en la ciudad de «las carretas de los moriscos de Aragón se han venido acoger y albergar a la ronda de la dicha ciudad a la dicha puerta de 
Albacices ${ }^{63}[\ldots]$ y allí cargan de lo que quieren, aunque al tiempo no sabe de qué» ${ }^{64}$. Monteagudo era lugar de paso continuo de los moriscos aragoneses de Torrellas o Santa Cruz, y sus dos vecinos moriscos tenían parientes en Borja, solían venir «horros ${ }^{65}$, con su cabalgadura», «aunque al tiempo, no sabe ni entiende que entre ellos haya confederación mala, sino [que] como son de mala casta no tienen dellos buena sospecha» ${ }^{66}$. Los mesoneros moriscos de Valtierra alojaban a numerosos miembros de su raza, merchantes, que pasaban a Borja o a Fréscano, de paso hacia Belchite, Almonacil, Calanda o incluso Valencia. Los tales mesoneros, según un vecino de Tudela eran tenidos «por malos cristianos y cree que viven en su ley y que hacen el ayuno de ramadán, como los demás moros» ${ }^{67}$.

El informe no era ajeno a las noticias y rumores que corrían de pueblo en pueblo sobre la presunta actividad de los moriscos aragoneses en la preparación de una asonada, mediante la acumulación de grano, armas y pólvora. Jerónimo Roldán, vecino de Tudela, que había vivido varios años en Cascante, conocía las numerosas recuas que pasaban por la villa de Cortes rumbo a Pamplona y viceversa, en las que traían hierro, plomo y estaño en mucha cantidad con objeto de «rebelarse y alzarse contra Su Majestad, porque no entiende que tanta cuantidad pueda ser para muy buen efecto» ${ }^{68}$. Un vecino de Buñuel, Miguel Lorenzo, lo tenía claro:

es pública voz y fama que han juntado gran cuantidad de trigo y bastimento y de armas y pólvora y munición y de todos metales para alzarse y dicen que

${ }^{63}$ Es probable que se refiera a la puerta de Albazares. Marín Royo, La Tudela desconocida, p. 185.

${ }^{64}$ AGN, Tribunales Reales. Procesos, n. ${ }^{\circ}$ 068395, fol. 23r-24v. Según dice uno de los testigos los moriscos que iban a Tudela con carretas de Aragón se alojaban habitualmente en las posadas y mesones de la plaza de las Herrerías, pero desde hacía tres o cuatros meses se habían mudado con sus carretas a la ronda cercana a la puerta de Albazares.

${ }^{65}$ Horro: «adjetivo que se aplica a la persona que es ya libre y antes era esclava [...] Significa también libre, desembarazado» [Aut.].

${ }^{66}$ AGN, Tribunales Reales. Procesos, n. ${ }^{\circ}$ 068395, fol. 22r-22v. Lo mismo ocurría con los de Cortes y sus contactos con aragoneses de Fréscano, Malón y otros lugares [AGN, Tribunales Reales. Procesos, n. ${ }^{\circ}$ 068395, fol. 26v y n. ${ }^{\circ} 28108$, fol. 94r], con los de Cascante, que mantenían un activo comercio con los núcleos moriscos de Torrellas, Malón, San Martín o Morata [AGN, Tribunales Reales. Procesos, n. ${ }^{\circ}$ 068395, fol. 29r-29v] o los de Ablitas con los de Malón «que son moriscos muy grandes bellacos» [AGN, Tribunales Reales. Procesos, n. ${ }^{\circ}$ 068395, fol. 31r].

${ }^{67}$ AGN, Tribunales Reales. Procesos, n. ${ }^{\circ} 068395$, fol. $1 \mathrm{r}$.

${ }^{68}$ AGN, Tribunales Reales. Procesos, n. ${ }^{\circ}$ 068395, fol. 26v. 
perderán antes sus vidas que dar las armas. Y ansí por lo que dicho tiene el testigo cree y tiene por averiguado que los dichos moriscos tienen mal propósito y se quieren alzar y rebelar y esto sabe. Y sabe ansí mismo que si algunas cosas traen a vender a este pueblo de Buñuel que procuran llevar el retorno en ámagos ${ }^{69}$ de cera y en hierro viejo. Y ansí mismo se dice públicamente que han vendido y venden sus haciendas para levantarse, las cuales venden [a] menos precio... ${ }^{70}$

Unos preparativos que se hacían, según los informantes, en connivencia con los rebeldes granadinos. El alcalde de las guardas de Tudela había oído que «estaban confederados con los de Granada para juntarse y ayudarse y ansí no habían hecho labranza como solían ni habían sembrado». "Y también había oído decir que se desbarataban de sus haciendas, no sabe a qué efecto, y cree que en todos los pueblos de Aragón hay muchas armas en poder de moriscos, especialmente en Torrellas» ${ }^{71}$, lugar conocido en la zona como "Argel el chico»» ${ }^{72}$. El guarda Miguel Navarro, atestiguaba que dos años antes de la sublevación de Granada pasaban escopetas procedentes de Guipúzcoa con destino a Torrellas. El mismo sostenía que:

oyó decir que en Torrellas hay mucho daño y que hay adalites ${ }^{73}$ que saben lo que en Granada pasa y puede seguir por esa razón, porque dese lugar corren a toda España y en quince días vien[en] nuevas de toda ella ${ }^{74}$.

69 Ámagos: «sustancia correosa y amarilla de sabor amargo que labran las abejas» [DRAE].

${ }^{70}$ AGN, Tribunales Reales. Procesos, n. ${ }^{\circ}$ 068395, fol. 30r. Según el alcalde de Buñuel, Antón Moncayo, «por aquella frontera de Buñuel y Cortes viven con miedo y temor los dichos moros porque están muy desarmados y no tienen con qué se defender». «Y que se dice públicamente que de los dichos metales hacen muchas armas y que están tan atemorizados que [...] con seis arcabuces los pueden sacar de sus casas...». Sospechas similares fueron transmitidas por los alcaldes de Monteagudo (fol. 22r-22v), Cascante (fol. 29r), Ablitas (fol. 31r), Tudela (fol. 1r), un mesonero de Tudela (fol. 7v$8 \mathrm{v}$ ) o testigos procedentes de Tarazona (fol. 9r) y otros lugares (fol. $4 \mathrm{v}-5 \mathrm{r}$ ).

${ }^{71}$ AGN, Tribunales Reales. Procesos, n. ${ }^{\circ}$ 068395, fol. 1r y ss. Estos datos son confirmados por otros guardas de las tablas de Tudela.

72 Testimonio del guarda de Tudela, Domingo de Lerga, AGN, Tribunales Reales. Procesos, n. ${ }^{\circ} 068395$, fol. $4 \mathrm{v}-5 \mathrm{r}$.

${ }^{73}$ Adalid: «Nombre arábigo; responde al nombre latino dux, seu ducens; es el que guía a otro y va enseñándole el camino que no es real ni ordinario, sino encubierto y hollado. En rigor se llama delid, mostrador, y porque de los adalides de fía todo un ejército» [Cov.].

${ }^{74}$ AGN, Tribunales Reales. Procesos, n. ${ }^{0}$ 068395, fol. 1r y ss. El tal Miguel Navarro confirmaba también que en los moriscos aragoneses no habían sembrado ni lino ni cáñamo. Varios vecinos consideraban a los moriscos maestros en la fabricación de armas de fuego. 
Los testigos también ofrecían otros testimonios que pretendían ser un reflejo del clima de alteración en el que vivían los moriscos aragoneses. Un clérigo de Atienza, mosén Juan, contaba al fiscal cómo los moriscos aragoneses vivían en su ley, ayunaban en Ramadán, no oían misa, no se confesaban, celebraban la Pascua de moros: "Y dicen a los cristianos y también al testigo "nosotros" y "vosotros", y llámanse "nosotros" a los moros y "vosotros" a los cristianos, y desta manera hacen de por sí sus ayuntamientos y alegrías, apartados en todo de los cristianos». Es más, recitaban por las calles, públicamente cánticos sediciosos: «Moriscos de Granada/ no creen en la ley mala» o bien, «Moriscos de la sierra/ no desmayedes/ que allá en el verano/ gran socorro habredes ${ }^{75}$.

Un hidalgo de Torrellas, Francisco Colmenares, decía haber oído a los moros del pueblo, tras el levantamiento de Granada: «En esa ley de cristianos, cada día se vuelven luteranos, y en esta nuestra de moros, estamos y estaremos fuertes». Hacían clara distinción -«divorcio»- «diciendo "nuestra ley de los moros" y "vuestra ley de los cristianos"». Además le habían dicho:

que este año setenta se perderá España y la tendrá y estará por moros, y a lo menos vosotros los cristianos no os tendremos Inquisición como vosotros nos la tenéis ahora, y seréis mejor tratados que nosotros lo somos de vosotros ${ }^{76}$.

También les había oído muchas veces pasar por las calles profiriendo cantares similares a los ya recogidos. Según el mismo, un tal Jerónimo Espiniel, hijo de un alfaquí, se refirió al Juan de Austria, encargado de aplastar la rebelión granadina, de esta forma: «Ese borde ${ }^{77} \mathrm{de}$ don Juan de Austria, vaya, vaya allá a la sierra, que allá le dirán quién él es y no a los que están rendidos» y le volvió a llamar "puto ${ }^{78}$, belitre ${ }^{79}$, borde». Y otros decían: «Esforza ${ }^{80}$, hermanos, que ahora ven-

75 AGN, Tribunales Reales. Procesos, n. ${ }^{\circ}$ 068395, fol. 10r-10v.

${ }^{76}$ Es un ejemplo del profetismo que ya describió Cardaillac, Moriscos y cristianos, p. $59-66$.

${ }^{77}$ Borde: «Significa algunas veces el hijo nacido de mujer no legítima, y aun mas en particular de la que ha tenido ruin fama, por haber sido común a muchos. El nombre es francés de bordeau, que nosotros llamamos burdel; vale lo que en latín lustrum, seu lupanar; pero en su originaria etimología es del nombre latino burdo, burdonis, por el animal hijo del caballo y del asna, que es el mulo» [Cov.].

78 Puto: «El hombre que comete el pecado nefando» [Aut.].

79 Belitre: «Pícaro, ruin, de poco o ningún valor y estimación y de viles procederes. Es voz francesa» $[$ Aut. $]$.

${ }^{80}$ Esforza: de esforzar «Dar vigor, ánimo y esfuerzo a alguna cosa, alentar, animar e infundir valor y aliento en alguno, $u$ tormarle para obrar con esfuerzo» [Aut.]. 
drán los moros de la sierra y degollaremos todos los cristianos», asegurando «que han de quedar señores absolutos de la tierra» ${ }^{81}$.

El miedo ante tales rumores incentivó, al menos entre los informantes, la necesidad de respuesta. El alcalde de Monteagudo se quejaba de que la población estaba desarmada y «tienen gran necesidad de armarse, porque tienen grandísimo miedo de los dichos moros, según los ven alborotados a los dichos moros» ${ }^{82}$. En Murchante «están con miedo dellos» ${ }^{83}$. Para el alcalde de Cortes, el más radical, la solución era matarlos porque de lo contrario «ellos las quitarán [las vidas] a nosotros si esto no se hace» ${ }^{84}$.

Este es el clima de tensión que se vivía en el sur del reino en 1570, alimentado, sin duda por otros informes similares ${ }^{85}$. Fuesen o no ciertos los rumores, el miedo a una guerra infame como la que se vivió por aquel entonces en las montañas alpujarreñas, y la noticia de la intranquilidad y tensión que se vivía en las comunidades aragonesas ${ }^{86}$, se extendió por doquier en los pueblos fronterizos.

Las medidas que se adoptaron fueron varias. En cuanto a los moriscos citados en el informe, solo los de Valtierra fueron llevados ante los tribunales. Martín Monje y Francisco Ramus y sus esposas, Isabel de Cuenda y María Ferrero, fueron acusados en 1570 de acoger en sus mesones especialmente a «moriscados de Aragón y Valencia» y de colaborar en el contrabando de armas. Además Francisco Ramus y su mujer habían

dicho por muchas y diversas veces a muchas personas que el rey de España no tenía razón ni sabía lo qué hacía en no dejalles vivir a los moros en su ley, porque si les dejase, en especial a los de Aragón, le pagarían dineros y vivirían contentos y que así lo hacía el gran turco, porque les dejaba vivir a los judíos en su ley y a los cristianos en la suya porque les pagasen dineros, y que por no dejalles así vivir se habían amotinado los dichos moros de Aragón y estaban para llevantarse contra los cristianos y se llevantarían porque estaban muy bien ar-

${ }^{81}$ Esforza: de esforzar «Dar vigor, ánimo y esfuerzo a alguna cosa, alentar, animar e infundir valor y aliento en alguno, $u$ tormarle para obrar con esfuerzo» [Aut.].

${ }^{82}$ AGN, Tribunales Reales. Procesos, n. ${ }^{\circ} 068395$, s. fol.

${ }^{83}$ AGN, Tribunales Reales. Procesos, n. ${ }^{\circ}$ 068395, fol. 25v. El mismo miedo que mostraban los testigos de Buñuel, Cortes (fol. 30r) o Ablitas (fol. 31r).

${ }^{84}$ AGN, Tribunales Reales. Procesos, n. ${ }^{\circ} 068395$, fol. 9v.

${ }^{85}$ Reglá, Estudios sobre los moriscos, p. 70. Sobre estos rumores que hablaban de un próximo levantamiento morisco en Aragón tras las Alpujarras, Cardaillac, Moriscos y cristianos, pp. 29-30.

${ }^{86}$ Benítez Sánchez-Blanco, Heroicas decisiones, pp. 291-309. 
mados y eran muchos más, que no los cristianos y ternían socorro de Turquía y se librarían.

Todo demostraba, según el fiscal, que tenían «odio contra su majestad y estar aunados con los dichos moros y de su bando» ${ }^{87}$. En la fase plenaria del proceso, los reos, que fueron encerrados en las cárceles reales de Pamplona, negaron todas las acusaciones, fruto de lo cual y de la falta de pruebas, se les dio libertad bajo fianza ${ }^{88}$.

Pero además de estas acciones derivadas directamente del informe del fiscal, hubo otras impulsadas por las autoridades civiles y eclesiásticas. El 18 de abril de 1569 se hizo pública una real provisión que ordenaba a las autoridades locales, bajo graves penas, a estrechar la vigilancia sobre los moriscos y restringía su comercio:

que no dejéis pasar en manera alguna por los pueblos de vuestra jurisdición a ningún moriscado de cualquiera condición y reino que sea sin que primero reconoscáis su persona y cargas que llevaren para efecto de saber si llevan armas, plomo o otra munición alguna y llevando cualquiera cosa dello los detengáis a los dichos moriscados y no les dejéis pasar y les quitéis las tales armas, plomo o munición que llevaren y terneis todo ello a nuestra mano real hasta que por nos vista vuestra noticia que dello diéredes se provea otra cosa. Lo cual cumplid y no hagáis lo contrario so pena de docientos ducados para nuestro fisco ${ }^{89}$.

Tales medidas contra el tráfico y circulación de mercancías volverían a repetirse con asiduidad los años que siguieron: en abril de $1570{ }^{90}$, el 1 de abril de 1575, o el 24 de febrero y el 28 de marzo de $1588^{91}$,

${ }^{87}$ AGN, Tribunales Reales. Procesos, n. ${ }^{\circ} 211763$, fol. 1r.

${ }^{88}$ En el mismo proceso también se les acusó de tener mujeres de mala vida en sus mesones, mozas a las que inducían a «echarse» con los huéspedes «en especial con los dichos moriscados de Aragón, a los cuales les decían se aprovechasen de las dichas mozas y a ellas les decían que recogiesen bien a los dichos moriscados y nos les hiciesen mal rostro y que se echasen con ellos». También inducían a muchas mujeres casadas, viudas y mozas de la villa. AGN, Tribunales Reales. Procesos, n. ${ }^{\circ} 211763$, fol. 1r.

${ }^{89}$ AGN, Tribunales Reales. Procesos, n. ${ }^{\circ}$ 029186, fol. 335r-335v. Reproducida también en AGN, Tribunales Reales. Procesos, n. ${ }^{\circ} 087540$, fol. 25r-25v.

${ }^{90}$ AGN, Tribunales Reales. Procesos, n. ${ }^{\circ} 029186$ y n. ${ }^{\circ} 087540$, fol. 22 r.

${ }^{91}$ AGN, Tribunales Reales. Procesos, n. ${ }^{\circ}$ 012244. Disposiciones complementarias de las órdenes que se había dado en 1575 y en 1593 para el desarme de los moriscos aragoneses en Lapeyre, Géographie de l'Espagne, p. 96 y otras en 1573, 1575, 1578, 1581, 1584 y 1586; Carrasco, Deportados, pp. 80-81; Epalza, Los moriscos, p. 67 o a las que aconsejaba el vicecanciller de Aragón hacia 1575. Reglá, Estudios sobre los moriscos, pp. 71-72. De 1588 es también una orden del virrey de Navarra, D. Luis Carrillo y Toledo dando licencia a la ciudad de Tudela para dar a Tarazona, Ejea, Tauste y Malón dos quintales de pólvora y uno de cuerda para atender una posible sublevación de moriscos. AMT [Archivo Municipal de Tudela], Lib. 19, n. ${ }^{\circ} 49$. 
coincidiendo con los rumores de posibles levantamientos en Aragón ${ }^{92}$.

Como consecuencia de tales órdenes se multiplicaron los procesos contra moriscos o contra quienes traficaban con armas de fuego y pólvora, así como con moneda o grano. En febrero de 1570, por ejemplo, Beltrán Palomo, morisco de Mallén, fue acusado en ausencia por intentar cruzar cobre por la frontera que «quería para llevarlo a las Alpujarras de Granada» ${ }^{93}$. También fueron apresados los vascongados Juan de Mallea y Juan de Arizala, que alardeaban de sus ganancias «pues los moriscos les daban y pagaban a como ellos querían» por transportar armas hacia Aragón ${ }^{94}$. Y así otros muchos ${ }^{95}$.

Esta persecución tuvo sus repercusiones económicas. En 1594, el arrendador de las tablas reales del reino de Navarra Lope de Echevelz, presentó una demanda contra el fiscal y el patrimonial del reino porque las condiciones bajo las que había firmado el contrato con la Corona no incluían prohibición alguna como la aprobada en abril de 1570. Él entendía que todo se debía al «levantamiento de los moros de Granada», pero para esa fecha ya estaban «reducidos y sujetos a las mesma sujeción y obediencia debida y que antes tenían». La disposición virreinal le había ocasionado pérdidas de más de seis mil ducados, pues el comercio de los moriscos de Aragón y Valencia en el reino «era mucha y de mucho provecho». Estimaba que semanalmente entraban en Navarra 200 machos y muchos carros, procedentes de Sestrica, Torrellas, Brea, Almonacid de la sierra de Calatayud, Calanda y de otros lugares de Aragón y Valencia. En efecto, los «moriscados» introducían en el reino «aceite, zafrán, jabón, sedas, paños, azúcar, confitura, conservas, higos, pasas, naranjas, arroz, avellanas, almendras y otras provisiones por no hacerse en este reino», y a cambio sacaban «fierro, ferraje, clavazón y metal». Al impedirse el comercio «padescen por

${ }^{2}$ Benítez Sánchez-Blanco, Heroicas decisiones, pp. 291-309, especialmente la grave crisis de 1574-75.

${ }^{93}$ AGN, Tribunales Reales. Procesos, n. ${ }^{\circ} 087540$.

94 AGN, Tribunales Reales. Procesos, n. ${ }^{\circ} 294624$, fol. 14r.

95 Son las causas contra los moriscos aragoneses Juan Vitrián [AGN, Tribunales Reales. Procesos, n. ${ }^{\circ}$ 001549], Jerónimo Barragán «a lo que se cree para con ellos hacer mal y matar a cristianos y repartir con otros moriscos» [AGN, Tribunales Reales. Procesos, n. ${ }^{\circ} 294621$ ], ambos en 1576; Juan Caslar en 1584 y varios carreteros moriscos de Sestrica en 1587 [AGN, Tribunales Reales. Procesos, n. ${ }^{\circ}$ 056691] y otros en 1589 [AGN, Tribunales Reales. Procesos, n. $^{\circ}$ 012244]. También fueron decomisadas cargas de cebada, además de armas, como en 1577 AGN, Tribunales Reales. Procesos, n. ${ }^{\circ} 028353$. 
causa de lo mesmo todo trabajo los dueños de las herrerías deste reino pues por la poca venta [están der] ruidas y los dueños perdidos y también los que en ellas trabajaban que casi era la mayor parte de toda la Montaña por faltarles este trabajo» ${ }^{96}$. También había afectado al tráfico de cebada del que se beneficiaban los navarros ${ }^{97}$.

Al mismo tiempo que las autoridades civiles aplicaban sus medidas contra la posible amenaza morisca, la Inquisición también llevó a cabo su propia persecución. Pero en Navarra, a diferencia de otros núcleos próximos ${ }^{98}$, sus efectos fueron mínimos, como consecuencia de la escasa población morisca en su territorio. En el tribunal de Logroño, según Contreras, fueron encausados 640 moriscos -un 19\% del total de procesos-, sobre todo en la década de los setenta, y, de manera espectacular en la de los ochenta, como podemos demostrar por nuestras propias investigaciones. De todos ellos -de los acusados ante el tribunal de Logroño-, poco más del 4\% (28 casos) tuvieron por objeto de persecución a moriscos residentes en Navarra, originarios, muchos de ellos de Castilla y, sobre todo, de Aragón.

¿Qué se persiguió? La práctica de «ritos y cirimonias de moros» - es decir, ayuno en el ramadán, las abluciones, la comida, «no comía tocino, ni bebía vino», el rezo de la zala, no tener imágenes, cantar canciones de moros, como la que comenzaba con las palabras «adórote profeta», etc.-, o porque decían «que también se podían salvar los moros en su ley como el cristiano» ${ }^{99}$. Luis Álvarez, un jabonero, natural de Granada, y residente en Tudela dijo:

[...] que había sido cosa muy injusta [quitar las armas a los moriscos aragoneses] y que de qué servía habérseles quitado no habiéndolos hallado en ninguna trai-

${ }^{6}$ AGN, Tribunales Reales. Procesos, n. ${ }^{\circ}$ 029186, fol. 1r y ss. La sentencia de la Cámara de Comptos absolvió al fiscal y al patrimonial. AGN, Papeles Sueltos de Comptos. Primera Serie, leg. 22, n. ${ }^{\circ} 17$.

${ }_{97}$ AGN, Tribunales Reales. Procesos, n. ${ }^{\circ} 098712$ y n. ${ }^{\circ} 070403$.

${ }_{98}$ Primero fueron perseguidos los de Granada, pero los moriscos de Zaragoza y de Valencia representaron entre el 60 y el $70 \%$ de las causas contra moriscos. Contreras considera que en el período entre 1560-1610 las causas de la Inquisición contra moriscos suponen el 31,6\% del total, un período de dureza parecida al que sufrieron los judíos de finales del siglo XV. Contreras, "Los moriscos", p. 477.

${ }_{99}$ Es el caso de Juan de Guadalajara, vecino de Tudela, en 1552-53 [AHN, Inquisición, lib. 833, fol. 63v], o del maestre Pedro, orcero, también en Tudela en 1554-55 «[...] porque dijo que el moro y el judío se podían salvar en su ley como el cristiano, y que ¿cuál de las tres leyes que Dios hizo era mejor?, y si había estado cierta persona en paraíso para saber lo que allí pasaba y cuál de las leyes era la mala o la buena» [AHN, Inquisición, lib. 833, fol. 65v]. 
Mapa 2. Procesos inquisitoriales contra moriscos residentes en Navarra (1550-1610)

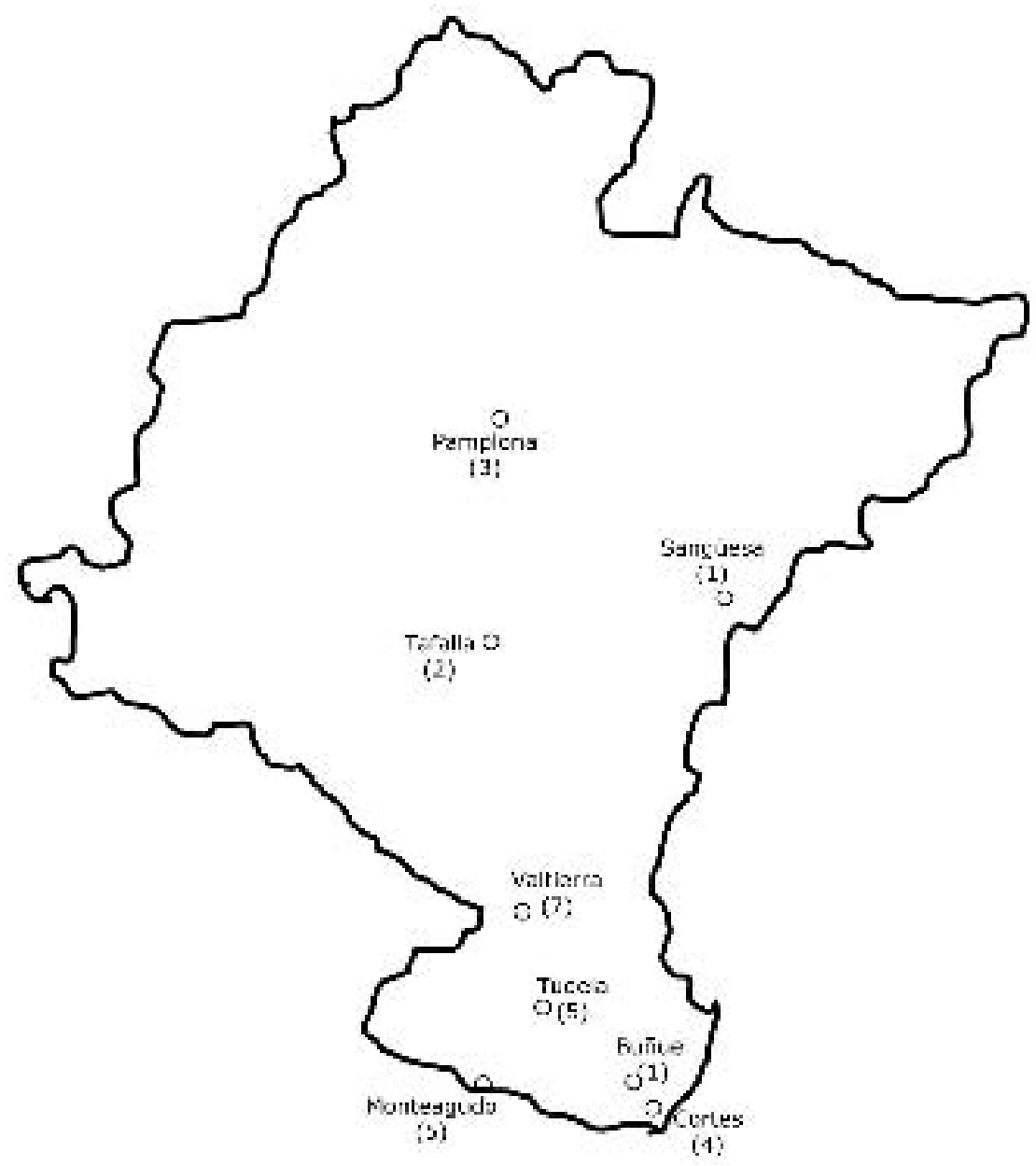

Fuente: Elaboración propia.

ción. Y que en Argel no hacían agravio a los cristianos como acá a los moros. Y que la Inquisición que había en España no era bien la hubiese sino dejar vivir a cada uno como quisiese. Y que la Inquisición servía de poner miedo al que quería ser moro, pero que no dejaba de serlo el que quisiese y de qué servía hacer cristiano a nadie por fuerza ${ }^{100}$.

${ }^{100}$ AHN, Inquisición, lib. 834, fol. 789v.

Al-Qanțara XXXIII 1, 2012, pp. 45-81 ISSN 0211-3589 doi: 10.3989/alqantara.2010.002 
Muchos de ellos pasaron por el tormento. La mayoría fueron reconciliados, se les confiscaron sus bienes, y fueron condenados a cárcel perpetua o a otras penas ejemplares ${ }^{101}$.

La Inquisición intensificó también la vigilancia y persecución de los moriscos que emigraban hacia Francia a través de Navarra, convertida en otra de las rutas - como la de Somport- de huida de moriscos aragoneses y castellanos ${ }^{102}$. Juan Hernández, alias Alheim, morisco procedente de Aranda y trabajador en las obras reales de Pamplona, fue denunciado en 1579-80 porque había dicho:

que muchos moriscos de Aragón se habían pasado con sus cosas y haciendas a Olorón de Francia donde todos eran luteranos. Diciendo que allá vivían como querían y que no tenían temor de la Inquisición. Y que él había acompañado dos mujeres moriscas que iban al dicho lugar y que en Pamplona estaban otros dos que se querían pasar a Francia. Y que él se había de juntar con otros moriscos que iban a Francia junto a Pamplona y que habían de volver por sus hijos y saldrían hasta Pamplona para acompañarlos. Y que también dijo al testigo el dicho reo que si él se quisiese ir a Olorón se iría con él y por haberse tenido aviso de la Inquisición de Zaragoza de los que así pasaban para que se prendiesen por haber salido de Aragón sin licencia ${ }^{103}$.

Por las mismas razones, por prestar ayuda a los moriscos que pasaban por Navarra hacia Olorón, fueron llevados a los tribunales inquisitoriales el mercader morisco de Sangüesa, Miguel de Liñán ${ }^{104}$ o don Juan de Castilla «hijo del rey de Fez» y residente en la fortaleza de Pamplona ${ }^{105}$, ambos en 1579 , o años más tarde, en 1587, el mesonero Pedro Ginés, de Valtierra ${ }^{106}$.

No parece, sin embargo, que los rumores de una conspiración entre hugonotes bearneses y moriscos tuvieran eco en la Inquisición de Logroño ${ }^{107}$. No así en Aragón, donde sí hubo noticias, escasamen-

101 Sobre la presencia morisca en los tribunales inquisitoriales de Logroño es muy recomendable el ilustrativo trabajo de Murillo, "Los moriscos ante la Inquisición", vol I. Otras referencias en Cardaillac, Moriscos y cristianos, pp. 32-43 y cap. II.

102 Monter, La otra Inquisición, pp. 245-246.

${ }^{103} \mathrm{AHN}$, Inquisición, lib. 833, fol. 486r. Fueron confiscados sus bienes y condenado a tres años de galeras.

${ }^{104}$ AHN, Inquisición, lib. 833, fol. 486r.

${ }^{105}$ AHN, Inquisición, lib. 833, fol. 533r. También fue acusado por lo mismo el mesonero pamplonés Gregorio de Zúñiga fol. 571v.

106 AHN, Inquisición, lib. 834, fol. 394r. Fue reconciliado, condenado a cárcel perpetua y los primeros cinco años en las galeras, además de cien azotes.

107 Existe algún testimonio esporádico, como el del jabonero morisco de Tudela, Luis Álvarez, que según los testigos había afirmado que «el haber quitado el rey las 
te fidedignas, en 1570, de que los moriscos granadinos habían enviado emisarios al Bearn solicitando la invasión de Navarra ${ }^{108}$.

El reino navarro también se vio afectado, al menos indirectamente, por la cruenta guerra entre montañeses aragoneses y moriscos en $1586-87^{109}$, y la aparición de los llamados «moros de venganza», bandoleros moriscos que pretendían vengarse de los cristianos viejos, organizados también en bandas. Navarra, en estos casos, fue, como nos recuerda Sánchez Aguirreolea, refugio de los montañeses que habían participado en las terribles masacres contra los moriscos y huían de la justicia aragonesa, y cuyos testimonios de las matanzas son estremecedores ${ }^{110}$. Testimonios que, sin duda, alimentaron el temor, el pánico, la desconfianza y el odio hacia la población morisca del otro lado de la frontera.

\section{La expulsión de 1609-1610}

Como he señalado, la ruptura que supuso la guerra de las Alpujarras fue determinante en el futuro de la consideración de los moriscos. Si bien es cierto que en los últimos años del XVI la presión de la Inquisición hacia ellos descendió considerablemente, las sospechas seguían vivas, y el clima de tensión fue permanente. Una nueva prohibición de mayo de 1607 de que los moriscos sacaran moneda del reino, multiplicó los procesos. En uno de ellos se afirmaba que en el reino y en Pamplona, en los dos últimos años

\footnotetext{
ha habido muchos presos moriscos del vuestro reino de Aragón, particularmente de la villa de Torrellas y Trasmoz [...] y han estado presos en vuestras cárceles reales muchos meses, y algunos dellos han sido condenados al tormento por haber entrado en este reino con mucha plata y habella trocado con moneda de vellón y llevado a las dichas villas y haberlos trocado y haberlos marcado con cuños contrahechos y después haberlos llevado a los vuestros reinos de Castilla, por doblalla como la han doblado ${ }^{111}$.
}

armas a los moriscos de Aragón era cosa muy injusta, los cuales por la mayor parte eran vasallos de los señores de Aragón que estaban huidos en Francia y se espantaba cómo no pedían favor al Turco y al que gobernaba en Francia para dar guerra al rey Don Felipe por el agravio que había hecho a los moriscos». AHN, Inquisición, lib. 834, fol. 789v.

108 Citado por Monter, La otra Inquisición, pp. 112-113.

${ }^{109}$ Colás Latorre y Salas Ausens, Aragón en el siglo XVI, pp. 597-610.

110 Sánchez Aguirreolea, El bandolero y la frontera, pp. 240-243.

111 AGN, Tribunales Reales. Procesos, n. ${ }^{\circ} 266439$, fol. 15r; otros procesos en AGN, 
Por estas fechas se produjo, al parecer, un nuevo flujo de emigrantes moriscos aragoneses hacia Navarra, lo que provocó la reacción de las Cortes del reino: la ley XXXII de las Cortes de Navarra de 1607-08, es un indicio claro del clima de ruptura que se vivía y de la fortaleza que habían adquirido las tesis de limpieza de sangre. En efecto, se quejaban de la llegada al reino de «nuevos convertidos de moros, so color que tienen oficios necesarios a las repúblicas, y algunos tienen tiendas y venden frutas, drogas y otras cosas de comer»». De ello «podrían resultar inconvenientes a este reino y sus vecinos, casándose con naturales cristianos viejos», por lo que pedían $-\mathrm{y}$ fue aceptado por el decreto real- que ningún morisco fuese admitido en el reino y que hiciera un listado de los que ya vivían en Navarra ${ }^{112}$.

Por otra parte, en los meses anteriores a la expulsión de los moriscos aragoneses corrieron rumores de la preparación de un levantamiento de los moriscos de Almonacir, Villafeliche y Tortoles, causando temor en Tarazona y Borja. El eco de estos movimientos llegó también a Navarra en donde el virrey Ponce de León dio aviso «de que unos moriscos andaban por aquel reino de noche y que estaba informado se recogían en Torrellas» ${ }^{113}$.

Pero ¿cómo afectó el destierro de los moriscos en el reino de Navarra? Es cierto que, como señala el carmelita Marcos de Guadalajara, si bien el monarca ordenó la expulsión de los moriscos castellanos y aragoneses «no tuvo que hacer en este reino» ${ }^{114}$, pero no por ello dejó de ser testigo de sus efectos. El destierro de los moriscos aragoneses se ordenó el 17 de abril de $1610^{115}$. En la instrucción que

Tribunales Reales. Procesos, n. ${ }^{\circ}$ 040891; 266439, 040887. También navarros participaron en este comercio: los vecinos de Tudela Mateo Ferriz, Felipe de Arellano y Pedro Castro, fueron detenidos y presos por trocar plata por moneda de vellón mientras recorrían las diferentes ferias de la Ribera con el fin de entregarla «secretamente» a los moriscos de Torrellas y Trasmoz. Según dice el fiscal, los moriscos marcaban después esa moneda y le daban un cuño falso.

112 Vazquéz de Prada y Usunáriz, Las Cortes de Navarra, vol. I, p. 480.

113 Guadalajara, Memorable expulsión, fol. $124 \mathrm{v}$. El autor no da demasiado crédito a estos temores al afirmar: «Llegado a querer apurar estas cosas, hallaron ser invenciones, nacidas y prohijadas del vano temor».

114 Guadalajara, Memorable expulsión, fol. 141v. Sobre la obra de este carmelita, Bunes, Los moriscos en el pensamiento histórico, pp. 40-45.

${ }_{115}$ Sobre su contenido y condiciones Reglá, Estudios sobre los moriscos, p. 92. Tras las órdenes de expulsión contra los moriscos castellanos de 1609 y 1610 estos fueron trasladados por Burgos e Irún. No se tiene noticia de que moriscos navarros formaran parte de estos contingentes expulsos. 
acompañaba a la misma, dirigida al virrey de Aragón, se daba noticia de cómo el monarca había dado orden al virrey de Navarra, don Manuel Ponce de León -precisamente uno los miembros de nobleza que se opuso a la expulsión ${ }^{116}$, , para que apercibiese gente de guerra en la frontera entre ambos territorios ${ }^{117}$. El 19 de junio de 1610 el monarca ordenó al virrey que dejase pasar por el territorio hacia Bearne a los moriscos «que llevasen pasaporte de Agustín de Mesía» ${ }^{118}$. A partir de entonces Ponce de León dispuso su tránsito, nombró comisarios «y dio orden al contador Martín Ochoa de Irigoyen (de quien tenía gran satisfación) que los recibiese y entregase a dichos comisarios conforme una larga instrucción que le fue entregada y ejecutada por él con su ordinaria prudencia» ${ }^{119}$.

Según los datos oficiales estos moriscos salieron por Vera, Roncesvalles y Somport, hasta en número de 22.532, mientras que 38.286 personas lo hicieron por el puerto valenciano de los Alfaques. De los más de veintidós mil que pasaron por la frontera pirenaica, $9.962^{120}$ lo hicieron por Navarra. No obstante, las fuentes navarras son parcas, casi inexistentes: un repaso a los protocolos notariales de Tudela, Villava, de Burguete, y de Vera o a los documentos de las tablas reales -peajes-, muestra que no contienen datos relevantes ${ }^{121}$.

Las primeras noticias nos hablan de algunos casos aislados, ajenos a la expulsión organizada. Gracias a un proceso de 1610 sabemos de la detención, en enero de ese año, de cinco moriscos, hombres y mujeres -acompañados de «tres criaturas chiquitas»- poco antes del decreto de expulsión, en la casa venta de Nuestra Señora del Yugo de Arguedas. Las contradicciones en sus declaraciones y el hecho de que no llevaran el salvoconducto obligado de la Inquisición, pues

116 Véase la carta de D. Manuel Ponce de León a S.M. de 28 de agosto de 1609. García-Arenal, Los moriscos, pp. 237-246. D. Manuel fue nombrado virrey de Navarra el 24 de agosto de 1609 y permaneció en el cargo hasta julio de 1610.

${ }^{117}$ Guadalajara, Memorable expulsión, fol. 133r-133v.

118 Se refiere a Agustín Mejía, miembro del Consejo de Guerra y encargado del ejército responsable de la expulsión de los moriscos de Valencia y Aragón.

119 Guadalajara, Memorable expulsión, fol. 142r. Guadalajara hace relación y tabla de los comisarios que los guiaron, los lugares que fueron removidos, el número de familias, de personas y el dinero que sacaron.

${ }^{120}$ Guadalajara habla de 9.965. Guadalajara, Memorable expulsión, fol. 139r.

121 Sabemos que hay algún testimonio sobre la expulsión en las actas municipales del ayuntamiento de Tudela, Libro 40, n. ${ }^{\circ}$ 30. 1610. Citado por Orta Rubio, "La Ribera tudelana", p. 804. Orta recoge también el testimonio de la construcción de una ermita cercana a Tudela en cuyas paredes se hizo esculpir la noticia de la expulsión. 
«ninguno desta nación puede caminar de unas a otras partes sin dichos albarés ${ }^{122}$ con sus nombres proprios» tuvieron como consecuencia que fuesen apresados y conducidos a Pamplona. Dos varones fueron llevados al tormento, mientras que a las mujeres nadie quiso darles posada en la ciudad. Finalmente todos ellos fueron remitidos a la Inquisición de Aragón, para continuar allí su causa ${ }^{123}$. El sábado quince de mayo de 1610, dos moriscos fueron asaltados, robados y asesinados por varios vecinos de Echarri-Aranaz ${ }^{124}$.

Fue en el verano de 1610 cuando la expulsión organizada dio lugar al paso de importantes contingentes por el reino. Según Lapeyre fue el virrey de Navarra, don Manuel Ponce de León, quien facilitó el paso de los exiliados por el reino tras negociar con las autoridades francesas. Gracias a ello, el virrey de Aragón dispuso la partida de 12 tropas de moriscos -alrededor de 2.100 familias y de 9.965 personas, procedentes sobre todo del valle del Jalón. Eran fundamentalmente gentes paupérrimas, a excepción de los procedentes de la localidad de Brea ${ }^{125}$. No obstante, por testimonios del fiscal del reino, todo apunta a que fue el arrendador de las tablas de Navarra, Fausto de Echauz, quien hizo gestiones para lograr la aprobación del paso de moriscos por Navarra e incrementar así su negocio ${ }^{126}$.

Las noticias más interesantes de este trasiego son las que nos ofrece la obra de Marcos de Guadalajara y Javier. Los primeros marcharon por Tudela y Villava y de allí a través del puerto de Vera desde donde cruzaban la frontera ${ }^{127}$. No obstante, la codicia de $\mathrm{Mr}$. d'Urtubie y de otros señores del sur de Francia, y especialmente la de los comisarios del gobernador de Bayona, hizo que se cambiase -no sin dificultades- el recorrido. Por esta razón, según Guadalajara, el virrey señaló el paso de Burguete para encaminar la expulsión «con mucha quietud y sosiego». No por ello se vieron libres de la presión

122 Albarés: por albaranes.

123 AGN, Tribunales Reales. Procesos, n. ${ }^{\circ} 121471$.

124 AGN, Tribunales Reales. Procesos, n. ${ }^{\circ}$ 041264. De los autores uno fue condenado a destierro perpetuo y a galeras. Otro logró huir gracias a la colaboración de varios cómplices que también fueron procesados. AGN, Tribunales Reales. Procesos, n. ${ }^{\circ}$ 057591 , fol. $18 \mathrm{v}$.

${ }^{125}$ Lapeyre, Géographie de l'Espagne, p. 102.

126 Según el fiscal Echauz fue a Lerma, Madrid y otras partes a pretender el paso de moriscos por el reino. AGN, Tribunales Reales. Procesos, n. ${ }^{\circ} 100981$.

127 Guadalajara, Memorable expulsión, fol. 142v. Citado por Janer, Condición social de los moriscos, p. 90, nota 15.

Al-Qanțara XXXIII 1, 2012, pp. 45-81 ISSN 0211-3589 doi: 10.3989/alqantara.2010.002 
de las autoridades francesas, que les obligaron a pagar un ducado por persona, a cambio de concederles «la gracia de poderse armar». Al poco tiempo, no obstante, les requisaron las armas y les compelieron «a vivir como cristianos», con lo que los moriscos «mudaron de puesto, con fin desastrado»» ${ }^{128}$.

Pero la codicia no fue solo pecado capital de los administradores franceses. Fueron dos los procesos judiciales que los moriscos de Brea (Zaragoza) interpusieron contra el arrendador de las tablas reales de Navarra, Fausto de Echauz y contra uno de sus oficiales, por cobro abusivo de derechos en las aduanas de Villava y Burguete. Uno de los pleitos se inició en 1610, el 11 de agosto, a iniciativa de los diputados y síndicos del reino, porque

a noticia suya ha venido que en la expulsión de los moriscos y paso que se les da por este reino al de Francia, el arrendador de las tablas y sus tenientes y tablajeros les hacen pagar y llevan derechos ecesivos, por cosas usadas y traídas, no debiéndose pagar cosa alguna por ellas ${ }^{129}$.

En efecto, el 9 de agosto de 1610, en Villava, el pregonero Juan de Olave anunciaba la orden del virrey por la que se obligaba a la «tropa» de moriscos a declarar -«manifestar»-, bajo pena de confiscación, todos sus bienes, «ansí ropa como dinero, oro, plata, joyas y cabalgaduras y todo lo demás que tuvieren» a cambio de una licencia y albarán de guía para atravesar el reino ${ }^{130}$, circunstancia que fue aprovechada por el arrendador Echauz para cobrar lo que consideraba sus derechos.

Algunos moriscos que se negaron a pagar los derechos abusivos de Echauz fueron detenidos. Entonces el justicia, jurados y regidores de Brea exigieron por carta -fechada en Zubiri, el 12 de agosto de 1610 - la liberación de los detenidos, «para partir todos juntos adonde Dios sea servido», «pues esta gente va en su desventura».

La tropa de moriscos llevaba 28.000 ducados y Echauz, por derechos de entrada y saca había recaudado un $8,33 \%$ hasta la cantidad de 25.660 reales, cuando solo podía cobrarles el $3 \%$ del dinero que portaban, -es decir, no más de 9.240 reales. El 12 de agosto el Consejo de Navarra ordenó al arrendador y a sus tablajeros que cobraran

${ }_{128}$ Guadalajara, Memorable expulsión, fol. 142v-143r. Citado por Janer, Condición social de los moriscos, p. 90, nota 15.

${ }^{129}$ AGN, Tribunales Reales. Procesos, n. ${ }^{\circ}$ 100981, fol. 1r.

130 AGN, Tribunales Reales. Procesos, n. ${ }^{\circ}$ 100981, fol. 103r. 
a los moriscos el 3\% estipulado por el dinero que llevaban, y no exigiesen ninguna contribución por los vestidos y ropas ${ }^{131}$, pues, según el fiscal, esto era a lo que se habían «allanado» el virrey de Aragón, el de Navarra y los del Consejo. También les había cobrado por las cabalgaduras, 261 jumentos, a razón de a cuatro reales por cabeza y por otros 260 mulos, mulas, yeguas y rocines que los había tasado «en lo que ha querido». Si lo pagaron fue «por no detener la tropa» ${ }^{132}$.

Echauz se defendió con el argumento de que lo que había cobrado era «mucho menor de lo que se pudiera, conforme a la ley», que establecía un 3,33\% por los derechos de entrada y un 5\% por los de saca. Además acusaba a los moriscos de que vendían lo que tenían en almoneda pública a cambio de moneda con lo que obtenían, según él, un beneficio de entre el 16 y el $18 \%$ y se ahorraban los portes. Es más «el lugar [Brea] no se ha agobiado, antes ha partido con mucho agradecimiento» y todo había sido una invención de los demandantes ${ }^{133}$.

Las sentencias de la Cámara de Comptos (el pleito, iniciado ante el Consejo, fue trasladado al tribunal de Comptos), fueron favorables a los moriscos, y ordenaron la devolución de todo lo cobrado, salvo la tasa estipulada del 3\% por el dinero. No obstante el pleito se prolongó durante varios años ${ }^{134}$ hasta que finalmente, el 26 de marzo de 1612, el Consejo absolvió a Echauz por sentencia definitiva ${ }^{135}$.

131 AGN, Tribunales Reales. Procesos, n. ${ }^{\circ}$ 100981, fol. 5v.

132 AGN, Tribunales Reales. Procesos, n. ${ }^{\circ}$ 100966, fol. 68r.

${ }^{133}$ AGN, Tribunales Reales. Procesos, n. ${ }^{\circ} 100966$, fol. 5r y 8r.

${ }^{134}$ El 12 de septiembre de 1610 los vecinos de Brea dieron poder a Hernando Sola, clérigo y procurador de la iglesia del Pilar de Zaragoza, a Agustín Oncino, notario real de Zaragoza, a Miguel Jiménez, procurador de los tribunales reales de Navarra y a tres vecinos de Pamplona para seguir los pleitos que tenían pendientes en los reinos de España. AGN, Tribunales Reales. Procesos, n. ${ }^{\circ} 100966$, fol. $77 \mathrm{r}$ y ss. Más adelante, y por una carta pública de venta, consta que los vecinos de Brea eran vasallos del cabildo del Pilar, y que estaban obligados a devolver 100 de las mulas y machos que llevaban consigo y que se habían obligado a restituir «en la lengua del agua o embarcadero donde se hubiesen de embarcar», pero como habían salido por tierra, no las habían devuelto. Por ello acordaban pagar los de Brea al cabildo a razón de 1000 escudos de a 10 reales como parte de pago, 500 directamente y los otros 500 de lo que les adeudaba Fausto de Echauz (para lo cual hicieron el correspondiente traspaso de la deuda de Echauz). AGN, Tribunales Reales. Procesos, n. ${ }^{\circ} 100966$, fol. 228r y ss.

135 Guadalajara, sin embargo, considera que los arrendadores salieron perdiendo, porque los moriscos hicieron declaraciones falsas sobre sus posesiones: «Para prueba de lo primero diré (siguiendo el parecer del licenciado Aznar y no mío, por sus 
Por las mismas fechas, el 15 de agosto de 1610, Pedro Zunzarren, en nombre del Consejo real, recibió información sobre los derechos cobrados por Martín de Aldasoro, arrendador del peaje de Burguete. Los abusos en Burguete habían sido similares: se les había cobrado derechos a la «ropa andada», y el arrendador del puerto había cobrado un real y medio por persona «chicas y grandes, hasta la que va en el pecho de la madre». Si bien es cierto que reconocían que «en nenguna parte deste reino ni el de Aragón, donde eran muy conocidos no han hallado tan buena acogida ni tanta piedad como en los vecinos desta villa» ${ }^{136}$. Ante esto, y a fin de evitar nuevas extorsiones, Pedro de Zunzarren reunió el 17 de agosto en un prado a otra tropa de moriscos procedentes de Luceni, Fréscano, Agón y Pleitas para advertirles de que, hasta que el Consejo no dijese lo contrario, no debían pagar derechos algunos al arrendador de Burguete. Ellos sin embargo se resignaron por propia necesidad, pues aun siendo verdad que no debían pagar peaje,

[...] a ellos les importa pagar más trescientos o cuatrocientos reales que les podrá venir de derechos, aunque no los deban, que detenerse un día, porque como yo el dicho secretario ha visto, hay muchísimos viejos y niños en el pecho de sus madres y otras muchísimas creaturas muy pequeñas y que todos duermen en el campo, en descubierta, padesciendo grande frío con el sereno. Y que están informados que en esta tierra llueve mucho, y que si les cogiese un temporal de aguas de noche, con el grande frío se les morirían muchos de los enfermos viejos y niños, y que así por esto, y por lo mucho que gastan todos los días, por ser cerca de mil personas, les importa más pagar lo que les pueda tocar de drechos de peaje, aunque no los deban, que detenerse ${ }^{137}$.

Los de Brea, sin embargo, sí se mostraron quejosos y continuaron pleito a través de un procurador. A pesar de los curiosos argumentos de Aldasoro -hasta entonces el arrendamiento del peaje le había ocasionado pérdidas en el último trienio, «y si no se ofrecie-

muchos ceros) que solos los moriscos de Brea, registraron en Navarra doscientos y cincuenta mil ducados, en dinero de oro y plata, sin otras cosas de grandísimo precio. Francisco Pariente, de Brea, registró cuarenta mil ducados en dinero. Manuel Granada de Apila, veinte mil. Juan Burro, de Huesca, diez mil. Los Ovejes de Almonacil de la Sierra, treinta mil. El Moreno de Nabal, Lope y Baltasar Alejandre de Barbastro, sin lo que llevaban consigo, enviaron delante quince mil. Y muchos sacaron a dos mil, a quinientos y a otros números mayores y menores». Guadalajara, Memorable expulsión, fol. 141r.

136 AGN, Tribunales Reales. Procesos, n. ${ }^{\circ}$ 100966, fol. 9r.

${ }^{137}$ AGN, Tribunales Reales. Procesos, n. ${ }^{\circ}$ 100966, fol. 10r. 
ra la expulsión de los moriscos por la dicha villa de Burguete, perdiera también muchos ducados este trienio ${ }^{138}$ 》)- los moriscos protestaron por los excesos del arrendador de Burguete. En efecto fueron amedrentados para pagar «y les fue fuerza callar» porque Aldasoro fue el comisario encargado de llevar la tropa a Francia desde Burguete, y él se entendía con los comisarios de Ultrapuertos. Sin esto «les podía hacer mucho mal y les convenía callar en aquella sazón, y por todas las vías procuraron no disgustarlo». Así tuvieron que soportar pagar real y medio por persona, «hasta los niños de pecho», que eran «cuatro mil personas y más» ${ }^{139}$. La sentencia de la Cámara de Comptos de 8 de noviembre de 1610 condenó a Aldasoro a devolver todos los derechos de más que había cobrado -no más del 3\% del dinero que llevaban los moriscos- y a una multa de 300 ducados que años más tarde, en mayo de 1612, fue revocada por el Consejo. Finalmente, por sentencia definitiva de 17 de noviembre de 1612, fue absuelto ${ }^{140}$.

No fueron los únicos en aprovechar la situación. Algunos tudelanos marcharon de la ciudad para ocupar las casas que habían abandonado los moriscos en los lugares limítrofes del reino de Aragón. En 1639 la ciudad de Tudela, a la petición del rey del envío de una leva de soldados para la guerra con Francia, respondió que «se ha hallado estar la mitad del lugar las casas caídas y cerradas...pues sabemos que hay lugares (de los que dejaron los moriscos despoblados en Aragón), poblados de solos vecinos de esta ciudad» ${ }^{141}$. Tenemos noticias de que al menos cuatro familias procedentes de Corella, Pamplona y Tudela, se habían asentado en la localidad de Tórtoles ${ }^{142}$ (véase Mapa 3).

Poco más conocemos sobre el impacto de aquella expulsión, salvo noticias esporádicas de apoyo a la medida. En 1617 el canónigo

${ }^{138}$ AGN, Tribunales Reales. Procesos, n. ${ }^{\circ}$ 100966, fol. 65r

139 AGN, Tribunales Reales. Procesos, n. ${ }^{\circ}$ 100966, fol. 68r.

140 AGN, Tribunales Reales. Procesos, n. ${ }^{\circ}$ 100966, fol. 58r, 234r-234v y fol. 273r. Hay constancia también de que Aldasoro fue compelido en San Juan de Pie de Puerto a devolver a los moriscos de Brea 2.000 reales, a instancias de Joan de la Forcada, miembro de la Chancillería de la Baja Navarra y diputado sobre la conferencia de Alduides y comisario en agosto de 1610 para pasar los moriscos por el puerto de Arranegui con destino a Bearne. Aldasoro pagó esa cantidad. AGN, Tribunales Reales. Procesos, n. ${ }^{\circ}$ 100966, fol. 268r.

${ }^{141}$ AGN, Guerra, leg. 3, carp. 73. Citado por Orta Rubio, "La Ribera tudelana”, p. 804.

142 Ainaga Andrés, "La repoblación", p. 91. 
MAPa 3. Lugares de origen de los moriscos expulsados por Navarra y caminos del destierro (1610)

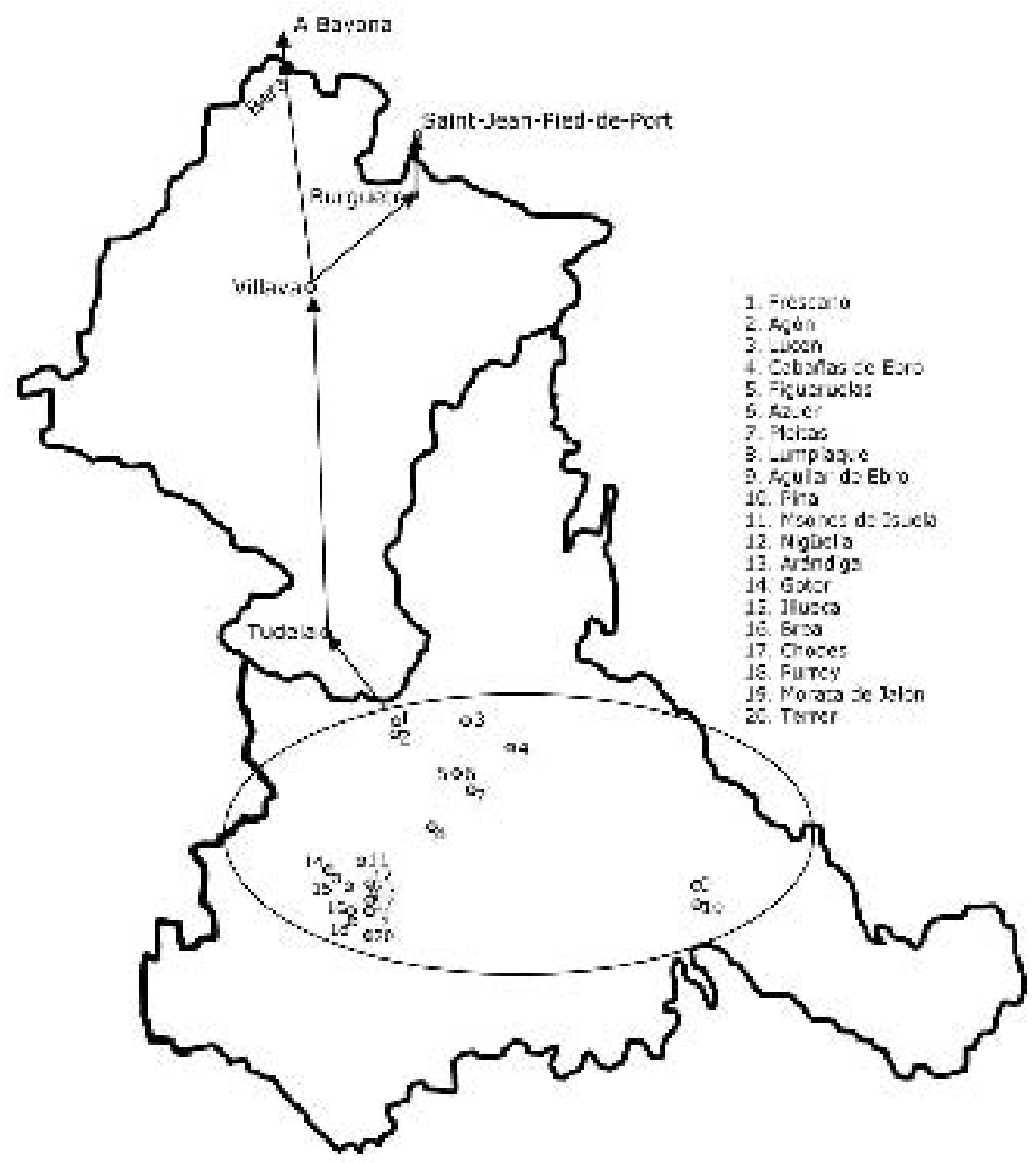

Fuente: Elaboración propia.

Juan de Huarte resumía, en su manuscrita Historia de Roncesvalles, los acontecimientos de aquellos años:

De la cual expulsión hay muchas historias, porque fue una de las insignes hazañas y maravillas que jamás se haya efectuado en España ni en otras partes de la Cristiandad, pues lo que no pudieron efectuar sus progenitores reyes poderosos 
con fuerzas de armas y derramamiento de sangre, éste con particular favor del cielo lo efectuó sin armas y sin efusión de sangre, echando innumerables moriscos fuera de España, como quien sacaba de un aprisco manadas de ganados para las dehesas. En conclusión ello fue milagro, pues una gente tan feroz y sangrienta y enemiga [...] salió de España como manadas de borregos. Atri[búyese] [...] al santo celo deste católico rey ${ }^{143}$.

\section{Conclusiones}

La expulsión o conversión forzada de los musulmanes navarros en 1516 fue consecuencia inmediata de la incorporación del reino a la Corona de Castilla. De los que se marcharon, muchos se refugiaron en Aragón y otros partieron hacia el norte de África. Sus posesiones fueron objeto de disputa entre la administración real, deseosa de recuperar el patrimonio del monarca, y la avidez de los señores particulares que quisieron beneficiarse de las circunstancias para adquirir nuevas tierras. Los «nuevamente convertidos» que permanecieron en el reino utilizaron los recursos legales para proteger sus posesiones, amenazadas también por los señores. El éxito de su empresa se debió, en buena parte, a que adquirieron la condición de navarros de pleno derecho, lo que facilitó, sin duda, su proceso de asimilación.

No obstante, los moriscos no se vieron libres de vigilancia, a pesar de lo cual parece claro que no se constituyeron comunidades moriscas en Navarra y que el peligro, a ojos de las autoridades, radicaba más en la presencia de moriscos aragoneses y su constante comercio, en un principio impulsado por las propias autoridades. La rebelión de los moriscos granadinos de las Alpujarras convirtió el recelo en miedo y dio lugar a una histeria colectiva que convirtió a los moriscos aragoneses en una amenaza para la seguridad interna y de las fronteras, como lo muestra el revelador informe, hasta ahora desconocido, del fiscal Pedro Lope de Lugo en 1570. La acción de los tribunales reales, de los virreyes y de la Inquisición creó una barrera de seguridad frente a los rumores de una posible sublevación aragonesa - primero en connivencia con Granada, después por iniciativa propia-y coaguló las relaciones de los aragoneses con los escasos moriscos navarros con los que mantenían el contacto. Esto, y los episodios de emigración de

${ }_{143}$ Huarte, J. de, Historia de Roncesvalles, 1617 [Manuscrito], Tercera parte, cap. 12, fol. 164 r.

Al-Qanțara XXXIII 1, 2012, pp. 45-81 ISSN 0211-3589 doi: 10.3989/alqantara.2010.002 
moriscos aragoneses hacia Navarra, incentivaron aún más el deseo de protección de la limpieza de sangre en el reino, algo que ya se había aplicado con referencia a los descendientes conversos de los judíos navarros, en un proceso ideológico aún por estudiar, en el que entraban en juego intereses políticos y económicos ${ }^{144}$.

El miedo, el fracaso de la asimilación cultural y de las campañas de evangelización, el celoso odio, los intereses económicos, una determinada política interior y exterior ${ }^{145}$-la del duque de Lerma en el primer tercio del siglo XVII ${ }^{146}$, ansiosa de «reputación» ${ }^{147}$, hicieron su labor a lo largo de un proceso complejo que acabó con la expulsión, de la que Navarra fue testigo indirecto y tangencial. Desde entonces, la huella morisca, como nos recuerda Alfredo Asiain, apenas dejó su marca en el viejo reino, salvo en algunos topónimos (moriscobidea-«camino del morisco») o en las imágenes sencillas, tópicamente elaboradas, de la literatura oral ${ }^{148}$.

\section{Bibliografía}

Ainaga Andrés, M. I., "La repoblación de los antiguos lugares moriscos: Tórtoles (Zaragoza), 1610-1670", Turiaso, 8 (1989), pp. 83-105.

Alonso Acero, B., "El norte de África en las relaciones entre moriscos y mundo islámico en torno a la Gran Expulsión", Estudis, 35 (2009), pp. 85-114.

Asiain, A., "Símbolos y superposiciones culturales y religiosas sobre el 'otro excluido' en la literatura oral navarra", Cuadernos de Etnología y Etnografia de Navarra, 74 (1999), pp. 463-496.

Benítez Sánchez-Blanco, R., Heroicas decisiones. La Monarquía Católica y los moriscos valencianos, Valencia, Institució Alfons el Magnànim-Diputació de València, 2001.

Bunes, M. Á., "Los moriscos en el mundo mediterráneo de los siglos XVI y XVII", Cartas de la Goleta, 2 (2009), pp. 53-64.

144 Usunáriz, "Limpios de mala raza".

${ }^{145}$ Son de gran interés las referencias de Benítez Sánchez-Blanco (Heroicas decisiones, pp. 374-378) a la vinculación entre la firma de la tregua de los 12 años con los holandeses en 1609 y la orden de expulsión.

146 Sobre la minoría morisca, su posición en la política mediterránea caracterizada por la tensión entre dos imperios durante los siglos XVI y XVII, el recrudecimiento de las acciones militares contra los musulmanes en el Mediterráneo por parte de Felipe III, Bunes, "Los moriscos en el mundo mediterráneo".

${ }^{147}$ Gelabert, "1609".

148 Asiain, "Símbolos y superposiciones". 
Bunes, M. Á., Los moriscos en el pensamiento histórico. Historiografía de un grupo marginado, Madrid, Cátedra, 1983.

Cardaillac, L., Moriscos y cristianos. Un enfrentamiento polémico (1492-1640), Madrid, Fondo de Cultura Económica, 1979.

Carrasco, R., Deportados en nombre de Dios. La expulsión de los moriscos: cuarto centenario de una ignominia, Barcelona, Destino, 2009.

Carrasco Pérez, J., "Los mudéjares de Navarra en la segunda mitad del siglo XIV (1352-1408): economía y sociedad”, Príncipe de Viana, Anejo, 2-3 (1986), pp. 75-107.

Carrasco Urgoiti, M. S., El problema morisco en Aragón al comienzo del reinado de Felipe II (Estudio y apéndices documentales), Teruel, Centro de Estudios Mudéjares, 2010, ed. facsimil de la ed. de Chapel Hill, University of North Carolina, 1969.

Colás Latorre, G., "Cristianos y moriscos en Aragón: una nueva lectura de sus relaciones y comportamientos en el marco de la sociedad rural", Mélanges de la Casa de Velázquez, 29, 2 (1993), pp. 162-169.

Colás Latorre, G., "Los moriscos aragoneses: estado de la cuestión y nuevas perspectivas", en VII Simposio Internacional de Mudejarismo, Teruel, Instituto de Estudios Turolenses-Centro de Estudios Mudéjares, 1999, 2 vols., pp. 783-796.

Colás Latorre, G. y Salas Ausens, J. A., Aragón en el siglo XVI. Alteraciones sociales y conflictos políticos, Zaragoza, Universidad, 1982.

Contreras, J., "Los moriscos en las inquisiciones de Valladolid y Logroño", en Les morisques et leur temps. Table Ronde Internationale 4-7 Juillet, Montpellier, 1981, París, CNRS, 1983.

Domínguez Ortiz, A. y Vincent, B., Historia de los moriscos: Vida y tragedia de una minoría, Madrid, Revista de Occidente, 1978.

Epalza, M. de, Los moriscos antes y después de la expulsión, Madrid, Mapfre, 1992.

García Arancón, R., "Algunas precisiones sobre la fiscalidad de los mudéjares navarros a mediados del siglo XIII", en Actas del V Simposio Internacional de Mudejarismo, Teruel, Instituto de Estudios Turolenses, 1991.

García-Arenal, M., "Los moros de Tudela en torno a los años de la conversión (1515)", en Les morisques et leur temps. Table Ronde Internationale 4-7 Juillet, Montpellier, 1981, París, CNRS, 1983.

García-Arenal, M., "Un nuevo documento árabe de Tudela. Año de 1509”, AlQantara, 5, 2 (1984), pp. 453-462.

García-Arenal, M., Los moriscos, Madrid, Editora Nacional, 1975.

García-Arenal, M. y Leroy, B., Moros y judios en Navarra en la baja Edad Media, Madrid, Hiperión, 1984.

García García, A. (dir.), Synodicon hispanum. VIII, Calahorra-La Calzada y Pamplona, Madrid, La Editorial Católica, 2007.

Al-Qanțara XXXIII 1, 2012, pp. 45-81 ISSN 0211-3589 doi: 10.3989/alqantara.2010.002 
Gelabert, J. E., “1609. Cuestiones de reputación”, Cartas de la Goleta, 2 (2009), pp. 39-52.

Goñi Gaztambide, J., Historia de los obispos de Pamplona. III, Pamplona, EUNSA, 1985.

Guadalajara, M. de, Memorable expulsión y iustisimo destierro de los moriscos de España, Pamplona, Nicolás de Asiain, 1613.

Janer, F., Condición social de los moriscos de España: causas de su expulsión y consecuencias que esta produjo en el orden económico y político, Madrid, Imprenta de la Real Academia de la Historia, 1857.

Lapeyre, H., Géographie de l'Espagne Morisque, París, SEVPEN, 1959.

López de Coca, J. E., "Notas y documentos sobre los mudéjares navarros despues de su expulsión del reino en 1516", Príncipe de Viana, Anejo, 9 (1988), pp. 155-164.

Marín Royo, L., La Tudela desconocida. Aspectos recónditos en la historia de la ciudad, Tudela, s.e., 2002.

Monter, E.W., La otra Inquisición: la Inquisición española en la Corona de Aragón, Navarra, el País Vasco y Sicilia, Barcelona, Crítica, 1992.

Murillo, S., "Los moriscos ante la Inquisición”, en Erro, C. y Mugueta, I. (ed.), Grupos sociales en la historia de Navarra, relaciones y derechos: actas del $V$ Congreso de Historia de Navarra, Pamplona, Sociedad de Estudios Históricos de Navarra, 2002, 3 vols., pp. 439-458.

Orta Rubio, E., "La Ribera tudelana bajo los Austrias: aproximación a su estudio socio-económico", Príncipe de Viana, 166-167 (1982), pp. 723-868.

Ozaki, A., "El régimen tributario y la vida económica de los mudéjares de Navarra", Príncipe de Viana, 178 (1986), pp. 437-484.

Reglá, J., Estudios sobre los moriscos, Barcelona, Ariel, 1974.

Salvador, E., "Sobre la emigración mudéjar a Berbería. El tránsito legal a través del puerto de Valencia durante el primer cuarto del siglo XVI", Estudis, 4 (1975), pp. 39-68.

Salvador, E., Felipe II y los moriscos valencianos. Repercusiones de la revuelta granadina (1568-1570), Valladolid, Universidad, 1987.

Sánchez Aguirreolea, D., El bandolero y la frontera. Un caso significativo: Navarra, siglos XVI-XVIII, Madrid, Iberoamericana, 2006.

Usunáriz, J. M., “'Limpios de mala raza': Injurias contra los judeoconversos en la Navarra del siglo XVI", en Insultar y maldecir en la cultura hispánica del Siglo de Oro, New York, Bern, Berlín, Bruxelles, Frankfurt am Main, Oxford, Wien, Peter Lang [en prensa].

Usunáriz, J. M., "La política de incorporación de señoríos a la Corona en la Navarra de la Edad Moderna", Studia Historica. Historia Moderna, 17 (1997), pp. 157-192.

Usunáriz, J. M., Nobleza y señoríos en la Navarra moderna. Entre la solvencia y la crisis económica, Pamplona, Eunsa, 1997.

Al-Qantara XXXIII 1, 2012, pp. 45-81 ISSN 0211-3589 doi: 10.3989/alqantara.2010.002 
Utrilla, J., El Fuero General de Navarra. Estudio y edición de las redacciones protosistémicas (Series A y B), Pamplona, Institución Príncipe de Viana, 1987.

Vázquez de Prada, V. (dir) y Usunáriz, J.M. (coord.), Las Cortes de Navarra desde su incorporación a la Corona de Castilla: tres siglos de actividad legislativa (1513-1829), Pamplona, Ediciones Universidad de Navarra, 1993, 2 vols.

Yanguas y Miranda, J., Diccionario de Antigüedades del Reino de Navarra, Pamplona, Diputación Foral de Navarra-Instituto Príncipe de Viana, 1963, 3 vols.

Recibido: $09 / 03 / 2010$

Aceptado: 30/05/2011 